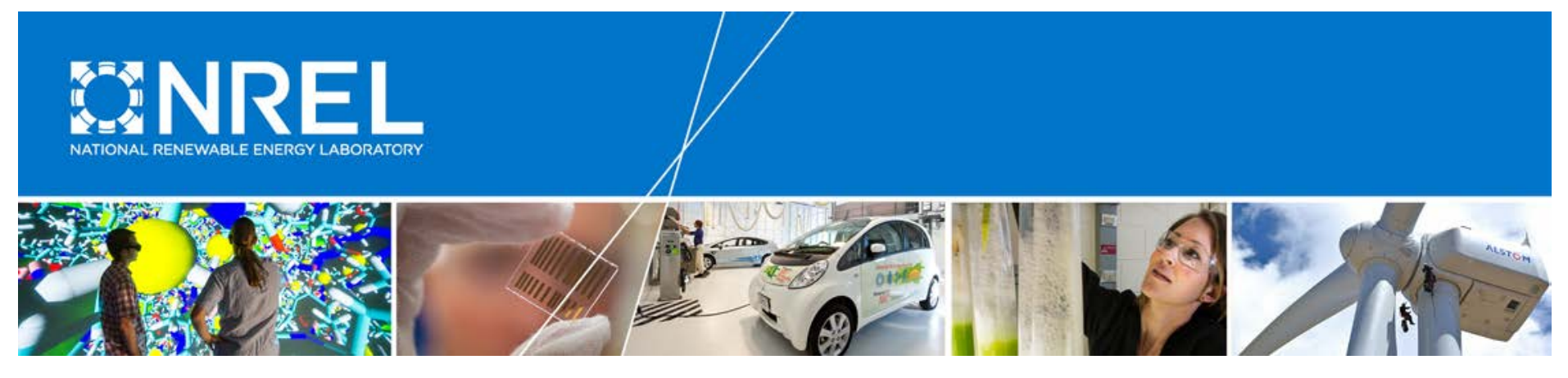

\title{
An Improved Global Wind Resource Estimate for Integrated Assessment Models
}

\section{Preprint}

Kelly Eurek, Patrick Sullivan, Michael Gleason, Dylan Hettinger, Donna Heimiller, and Anthony Lopez

National Renewable Energy Laboratory

To be published in Energy Economics

NREL is a national laboratory of the U.S. Department of Energy Office of Energy Efficiency \& Renewable Energy Operated by the Alliance for Sustainable Energy, LLC

This report is available at no cost from the National Renewable Energy Laboratory (NREL) at www.nrel.gov/publications.

\section{Journal Article}

NREL/JA-6A20-65323

February 2017 


\section{NOTICE}

The submitted manuscript has been offered by an employee of the Alliance for Sustainable Energy, LLC (Alliance), a contractor of the US Government under Contract No. DE-AC36-08GO28308. Accordingly, the US Government and Alliance retain a nonexclusive royalty-free license to publish or reproduce the published form of this contribution, or allow others to do so, for US Government purposes.

This report was prepared as an account of work sponsored by an agency of the United States government. Neither the United States government nor any agency thereof, nor any of their employees, makes any warranty, express or implied, or assumes any legal liability or responsibility for the accuracy, completeness, or usefulness of any information, apparatus, product, or process disclosed, or represents that its use would not infringe privately owned rights. Reference herein to any specific commercial product, process, or service by trade name, trademark, manufacturer, or otherwise does not necessarily constitute or imply its endorsement, recommendation, or favoring by the United States government or any agency thereof. The views and opinions of authors expressed herein do not necessarily state or reflect those of the United States government or any agency thereof.

This report is available at no cost from the National Renewable Energy Laboratory (NREL) at www.nrel.gov/publications.

Available electronically at SciTech Connect http:/www.osti.gov/scitech

Available for a processing fee to U.S. Department of Energy and its contractors, in paper, from:

U.S. Department of Energy

Office of Scientific and Technical Information

P.O. Box 62

Oak Ridge, TN 37831-0062

OSTI http://www.osti.gov

Phone: 865.576.8401

Fax: 865.576.5728

Email: reports@osti.gov

Available for sale to the public, in paper, from:

U.S. Department of Commerce

National Technical Information Service

5301 Shawnee Road

Alexandria, VA 22312

NTIS http://www.ntis.gov

Phone: 800.553 .6847 or 703.605 .6000

Fax: 703.605.6900

Email: orders@ntis.gov 


\title{
An improved global wind resource estimate for integrated assessment models
}

\author{
Kelly Eurek, Patrick Sullivan†ं, Michael Gleason, Dylan Hettinger, Donna Heimiller, Anthony
} Lopez

National Renewable Energy Laboratory, 15013 Denver West Parkway, Golden, CO, USA 80401-3305

$\dagger$ Current affiliation ${ }^{1}$ is Tendril, Inc., $258055^{\text {th }}$ Street, Boulder, CO, USA 80301

Corresponding author email: kelly.eurek@nrel.gov, Tel.: +1 3032754289

psullivan@tendrilinc.com, michael.gleason@nrel.gov, dylan.hettinger@nrel.gov, donna.heimille r@nrel.gov, anthony.lopez@nrel.gov

\section{Abstract}

This paper summarizes initial steps to improving the robustness and accuracy of global renewable resource and techno-economic assessments for use in integrated assessment models. We outline a method to construct country-level wind resource supply curves, delineated by resource quality and other parameters. Using mesoscale reanalysis data, we generate estimates for wind quality, both terrestrial and offshore, across the globe. Because not all land or water area is suitable for development, appropriate database layers provide exclusions to reduce the total resource to its technical potential. We expand upon estimates from related studies by: using a globally consistent data source of uniquely detailed wind speed characterizations; assuming a non-constant coefficient of performance for adjusting power curves for altitude; categorizing the distance from resource sites to the electric power grid; and characterizing offshore exclusions on the basis of sea ice concentrations. The product, then, is technical potential by country, classified by resource quality as determined by net capacity factor. Additional classifications dimensions are available, including distance to transmission networks for terrestrial wind and distance to shore and water depth for offshore. We estimate the total global wind generation potential of 560 $\mathrm{PWh}$ for terrestrial wind with $90 \%$ of resource classified as low-to-mid quality, and $315 \mathrm{PWh}$ for offshore wind with $67 \%$ classified as mid-to-high quality. These estimates are based on $3.5 \mathrm{MW}$ composite wind turbines with 90 meter hub heights, 0.95 availability, $90 \%$ array efficiency, and $5 \mathrm{MW} / \mathrm{km}^{2}$ deployment density in non-excluded areas. We compare the underlying technical assumption and results with other global assessments.

\section{Keywords}

wind, supply curve, resource assessment, technical potential, integrated assessment model, global

\section{Highlights}

- We develop global supply curves for wind-based electric power generation.

- We utilize location-specific, inter-annual, statistical wind speed data.

${ }^{1}$ The author's contributions to this work were done at the National Renewable Energy Laboratory. 
- We classify the wind resource by country, quality and accessibility.

- We present these supply curves for use in global integrated assessment models.

\section{Classification Codes}

O210, Q200, Q210, Q420, Q540

Abbreviations
\begin{tabular}{|l|l|}
\hline AGL & Above Ground Level \\
\hline CFDDA & Climate Four Dimensional Data Assimilation \\
\hline EEZ & Exclusive Economic Zone \\
\hline IPCC & Intergovernmental Panel on Climate Change \\
\hline IEC & International Electrotechnical Commission \\
\hline IUCN & International Union for the Conservation of Nature \\
\hline NCAR & National Center for Atmospheric Research \\
\hline NOAA & National Oceanic and Atmospheric Administration \\
\hline NREL & National Renewable Energy Laboratory \\
\hline nCF & Net Capacity Factor \\
\hline NRMSD & Normalized Root Mean Square Deviation \\
\hline
\end{tabular}

\section{Nomenclature}

\begin{tabular}{|c|c|l|}
\hline Symbol & Units & Definition \\
\hline $\boldsymbol{U}$ & $\mathrm{m} / \mathrm{s}$ & Distribution of wind velocities in the northward wind direction \\
\hline$\rho_{i}$ & $\mathrm{~m} / \mathrm{s}$ & Distribution of wind velocities in the eastward wind direction \\
\hline$Z_{i}$ & $\mathrm{~m}$ & Air density of site $\boldsymbol{i}$ \\
\hline$P$ & $W$ & Turtitude of ground level at site $\boldsymbol{i}$ \\
\hline$C_{p}$ & - & Coefficient of performance \\
\hline$\rho$ & $\mathrm{kg} / \mathrm{m}^{3}$ & Air density \\
\hline$A$ & $\mathrm{~m}^{2}$ & Turbine swept area \\
\hline$v$ & $\mathrm{~m} / \mathrm{s}$ & Wind speed \\
\hline$P_{\text {ref }}$ & $M W$ & Wind turbine power output at reference air density \\
\hline$P_{\text {adj }}$ & $M W$ & Wind turbine power output adjusted for altitude \\
\hline$\rho_{\text {ref }}$ & $\mathrm{kg} / \mathrm{m}^{3}$ & Reference air density \\
\hline$\rho_{\text {adj }}$ & $\mathrm{kg} / \mathrm{m}^{3}$ & Air density adjusted for altitude \\
\hline$v_{\text {adj }}$ & $\mathrm{m} / \mathrm{s}$ & Wind speed adjusted for altitude \\
\hline$v_{\text {ref }}$ & $\mathrm{m} / \mathrm{s}$ & Wind speed at reference air density \\
\hline$\eta_{\text {avail }}$ & - & Turbine availability \\
\hline$\eta_{\text {array }}$ & - & Turbine array efficiency \\
\hline$n C F_{t, i}$ & - & Net capacity factor for month-hour $\boldsymbol{t}$ at site $\boldsymbol{i}$ \\
\hline$E\left[P_{t, i}\right]$ & $M W$ & Expected power output for month-hour $\boldsymbol{t}$ at site $\boldsymbol{i}$ \\
\hline$\delta$ & $M W / k m^{2}$ & Turbine deployment density \\
\hline$P_{\text {rated }}$ & $M W$ & Turbine rated power output \\
\hline$A_{i}^{\text {avail }}$ & $\mathrm{m}$ & Available area at site $\boldsymbol{i}$ \\
\hline$P o t_{i}^{\text {cap }}$ & $M W$ & Capacity potential at site $\boldsymbol{i}$ \\
\hline$P o t_{i}^{\text {gen }}$ & $M W h / y r$ & Generation potential at site $\boldsymbol{i}$ \\
\hline
\end{tabular}




\section{Introduction}

Limiting and reducing emissions of greenhouse gases to mitigate global climate change is to a large part a long-term challenge affecting the global energy sector. Renewable energy technologies have the potential to contribute substantially to supplying energy at low greenhouse gas emissions. The 2011 Special Report on Renewables by the Intergovernmental Panel on Climate Change (IPCC) reviewed the published scientific global scenario literature that covers a large number of integrated assessment models. It finds considerable variations of renewable energy technology deployment levels for the coming decades ranging from negligible to substantial: some scenarios exceed $400 \mathrm{EJ} /$ year of renewable energy, up from about $64 \mathrm{EJ}$ actually produced in 2008 (IPCC 2011). The report documents substantial knowledge gaps with respect to (1) the economic resource potential under various scenarios of future development, and (2) the potential role of renewable energy technologies in the context of an integrated climate change mitigation strategy.

Ongoing energy-economic analysis at the country, regional, and international levels, including the activities of the Energy Modeling Forum, the Integrated Assessment Modeling Consortia, and many independent policy and technology analysis activities, plus the publication of the fifth assessment report (AR5) of the IPCC (2014), represents the breadth of related research of climate change mitigation strategies and other related policy and technology analyses. These policy-relevant research tasks address key questions related to the role of energy technologies for climate mitigation (as well as a host of additional policy goals) and offer the opportunity to address knowledge gaps and to more accurately assess the potential role of renewable energy in deployment scenarios. In particular, scenarios developed with integrated assessment models that deploy wind and solar energy resources at large scale and integrate these variable sources into the electricity system can be substantially improved.

Motivated by the need for an improved representation of renewable energy technologies in global modeling scenarios, we summarize initial steps to enhancing the robustness and accuracy of global wind resource assessments: the development of a method to construct country-level resource supply curves, delineated by resource quality and other parameters. The resource supply curves around which this paper is organized are produced by the National Renewable Energy Laboratory (NREL).

In developing the methodologies and assumptions for the NREL supply curves, we explore the approaches from three related global wind studies: To estimate global terrestrial wind potential, Hoogwijk et al. (2004) start with the Climate Research Unit dataset, extrapolate wind speeds to a $90 \mathrm{~m}$ hub height using a logarithmic wind speed profile, and estimate full load hours as a function of wind speed using the characteristics of the Weibull distribution and six commercial wind turbines. The authors apply exclusions to remove sites based on wind regime, high altitudes, urban areas, biological reserves, and land use suitability. To estimate global offshore wind potential, Arent et al. (2012) start with the National Oceanic and Atmospheric Administration's (NOAA) Blended Sea Wind global ocean surface dataset, extrapolate annual average wind speeds to a $90 \mathrm{~m}$ hub height using the wind profile power law, and estimate power output by convolving a Weibull wind speed distribution with a $3.5 \mathrm{MW}$ composite turbine power curve. The authors apply exclusions layers to remove sites in protected areas, sites very near and far to shore, and sites in overly deep waters. To estimate both global terrestrial and offshore wind 
potential, Lu et al. (2009) use the Goddard Earth Observing System (GEOS) Data Assimilation System (DAS) dataset, estimate wind speeds at a 100m hub height using a cubic spline fit of wind speed data at multiple heights above ground level, and estimate power output using 2.5 and 3.6 MW turbine power curves. For terrestrial wind, the authors adjust for lower air density at elevation and apply exclusion layers to remove terrestrial sites based on permanent snow, ice, water, developed and urban areas, forests, and extreme slope. For offshore wind, the authors exclude sites very near and far to shore, and sites in overly deep waters. Minimum resource quality constraints also apply.

In this current work, we present resource supply curves for both terrestrial and offshore wind using globally consistent, uniquely detailed, wind speed characterizations from the Climate Four Dimensional Data Assimilation (CFDDA) mesoscale reanalysis climate dataset (NCAR 2011). This unique dataset includes, (1) location-specific statistical parameterization of wind velocities (means, variances, and covariances) which allow us to customize wind speed distributions based on mesoscale model outcomes; (2) intra-annual temporal resolution which captures seasonal effects missed by an annual average; and (3) wind data at multiple elevations above the ground surface which inform better estimates for wind speeds at hub height. We create wind speeds distribution and convolve them with $3.5 \mathrm{MW}$ composite turbines to estimate power output for a representative wind farm at each location. Similar to prior work (Hoogwijk et al. 2004; Arent et al. 2012; Lu et al. 2009), we use geospatial filters to exclude areas deemed unlikely to be developed, and we classify remaining area by resource quality and accessibility. Expanding upon prior work, we assume a non-constant coefficient of performance for adjusting power curves for altitude, categorize the distance from a terrestrial resource site to the electric power grid, and include offshore exclusions on the basis of sea ice concentrations.

The paper is structured to move through the process sequentially, from discussion of the raw resource dataset, through descriptions of the resource classification and filtering methods, to an evaluation of the resulting supply curves. A comparison of resulting wind deployment and levelized costs of energy in the models can be found in "Luderer, G., Pietzcker, R.C., Carrara, S., de Boer, H.S., Fujimori, S., Johnson, N., Mima, S., Arent, D., in this issue. An introduction to a special section on the role of wind and solar power for the global low-carbon energy transformation." 


\section{Estimating Wind Energy Output}

\subsection{Wind Resource Dataset}

The underlying dataset for the NREL global wind resource supply curves is the National Center for Atmospheric Research's (NCAR) Climate Four Dimensional Data Assimilation (CFDDA) mesoscale climate reanalysis database, a 21-year collection of hourly, global, modeled climate data for 1985-2005, backed by surface and upper-air observations and measurements that are incorporated into the core mesoscale modeling (NCAR 2011). ${ }^{2}$ The dataset is spatially resolved as equidistant latitude-longitude 0.4 degree $(\sim 40 \mathrm{~km})$ grid, ${ }^{3}$ at multiple layers including four within $200 \mathrm{~m}$ above ground level (AGL): $15.7 \mathrm{~m}, 58.1 \mathrm{~m}, 115.1 \mathrm{~m}$, and $179.2 \mathrm{~m}$. From hourly wind velocity vectors in the northward and eastward wind direction at each site, we have mean and standard deviation of those vectors and a cross-direction covariance at each month-hour. A month-hour is an average hour of a day in a given month, e.g., January 12 p.m. In total there are 288 month-hours (12 months x 24 average hours per month). The multiples years of hourly data are summarized by month-hours to reduce data storage requirements while preserving temporal wind characteristics.

\subsection{Estimating Wind Speed Distributions}

In order to estimate the expected annual energy output from a wind turbine at a particular site, we seek information about the distribution of wind speeds. In the absence of this information, Arent et al. (2012) assume a Weibull distribution with a shape parameter $k=2$. In examining the parameterization of Weibull wind speed distributions, Seguro and Lambert (2000) note that the value of the shape parameter $k$ typically ranges between 1.5 (more gusty winds) and 3 (less gusty winds), and that $k=2$ corresponds to moderately gusty winds. Therefore, Arent's assumption of $k=2$ generalizes global wind regimes as moderately gusty.

The unique month-hour wind velocity vector statistics included in the CFDDA dataset (mean, variance, and cross-direction covariance) offer an opportunity to characterize the distribution of wind speeds based on mesoscale model outcomes rather than using the standard Weibull assumption. Therefore, we use these statistics to define northward $(\boldsymbol{U})$ and eastward $(\boldsymbol{V})$ wind velocity distributions and convert them into resultant wind speed distributions.

Because we do not know the shape of the $\boldsymbol{U}$ and $\boldsymbol{V}$ velocity distributions, we assume them to be normally distributed with the means and variances from the CFDDA dataset. We validate this assumption using two decades of 10-minute average wind speed measurements from twelve data collection buoys ${ }^{4}$ located in U.S. waters at various distances to shore (see Figure 1). We estimate the normalized root mean square deviation (NRMSD) between distributions of measured wind velocities (from the offshore data buoys) and simulated normal distributions (constructed using the means and variances of the measured data). Considering all 288 month-hours for all twelve

\footnotetext{
${ }^{2}$ The CFDDA dataset used for this analysis is created from the $5^{\text {th }}$ generation mesoscale model (MM5) version 3.6. (Grell et al. 1995).

${ }^{3} \mathrm{We}$ apply the Mollweide projection to produce equal-area $40 \mathrm{~km}$ cells at the expense of distorting the shape of cells, especially at upper and lower latitudes.

${ }^{4}$ The data buoys are owned and maintained by the National Data Buoy Center:

http://www.ndbc.noaa.gov/. Accessed August 3, 2016.
} 
sites, we find the median deviations to be $5.4 \%$ and $4.3 \%$ in the northward and eastward directions. Figure 2 shows a histogram of the deviations for each wind direction.

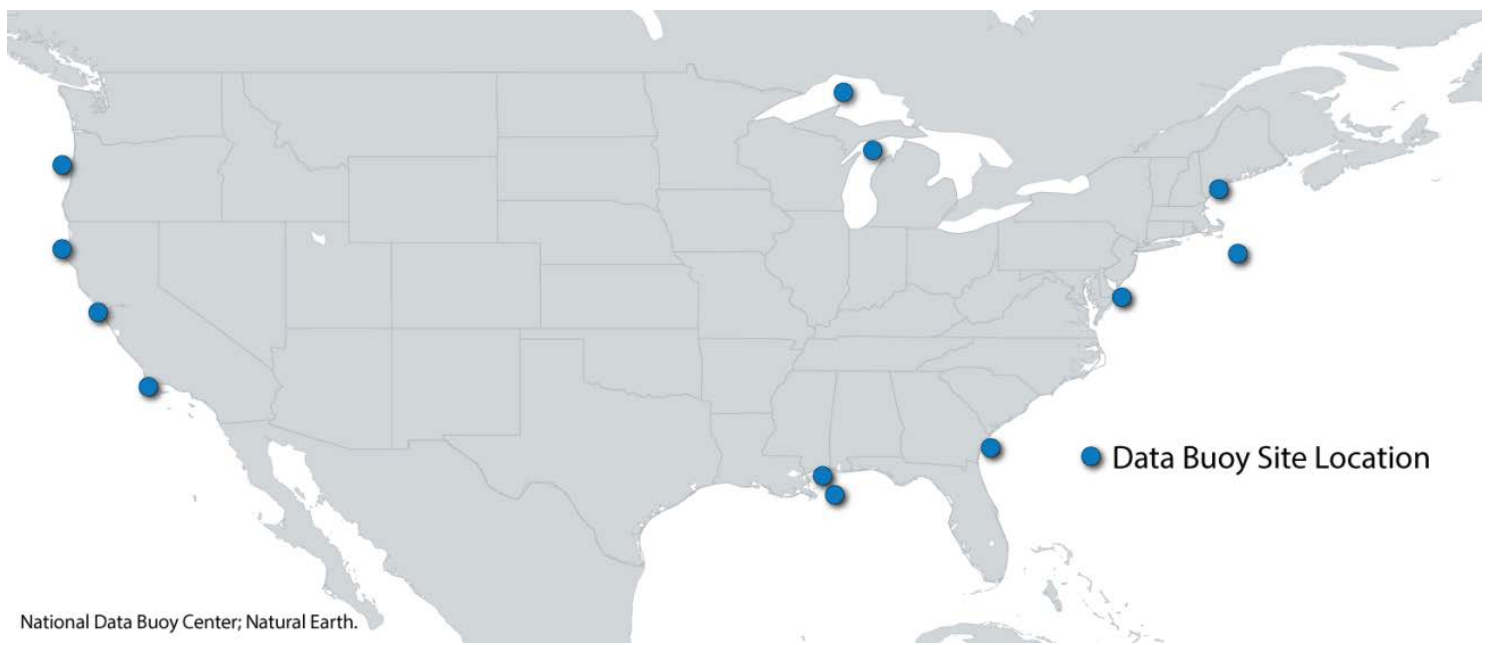

Figure 1. Locations of data collection buoys. The historical buoy data are used to derive distributions of wind velocities.
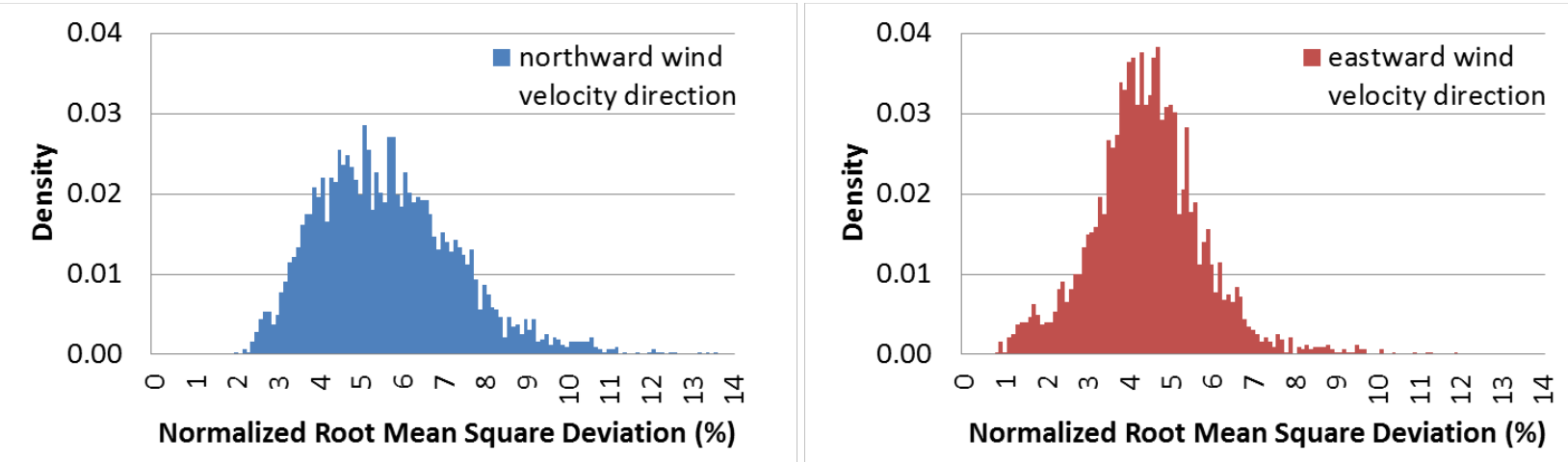

Figure 2. Histograms of the normalized root mean square deviations between distributions of measured wind velocities (from offshore data buoys) and simulated normal distributions (constructed using the means and variances of the measured data) in the northward and eastward wind directions for 288 month-hours at twelve data buoy sites.

Assuming normal distributions, we define $\boldsymbol{U}$ and $\boldsymbol{V}$ using the means, variances, and crossdirection covariances from the CFDDA dataset. First, we sample $n$ random numbers from a unit normal distribution for each wind direction (we use $n=10,000$ ). Applying Cholesky decomposition, we adjust the random sample for the eastward direction such that the elements are appropriately correlated (based on the cross-direction covariance) with the random sample for the northward direction. Then we transform the correlated random samples into the $\boldsymbol{U}$ and $\boldsymbol{V}$ wind velocity distributions by applying the means and variances. Finally, we combine the correlated $\mathrm{u}-\mathrm{v}$ pairs to calculate resultant scalar wind speeds and create a distribution of wind speeds for each height and month-hour.

We validate the above approach by calculating the NRMSD between distributions of measure wind speeds (from offshore data buoys) and simulated resultant wind speed distributions 
(constructed using the mean, variance, and cross-direction covariance of the measured data). Considering all 288 month-hours for all twelve data buoy sites, we find the median deviation to be $4.9 \%$. Figure 3 shows a histogram of the deviations.

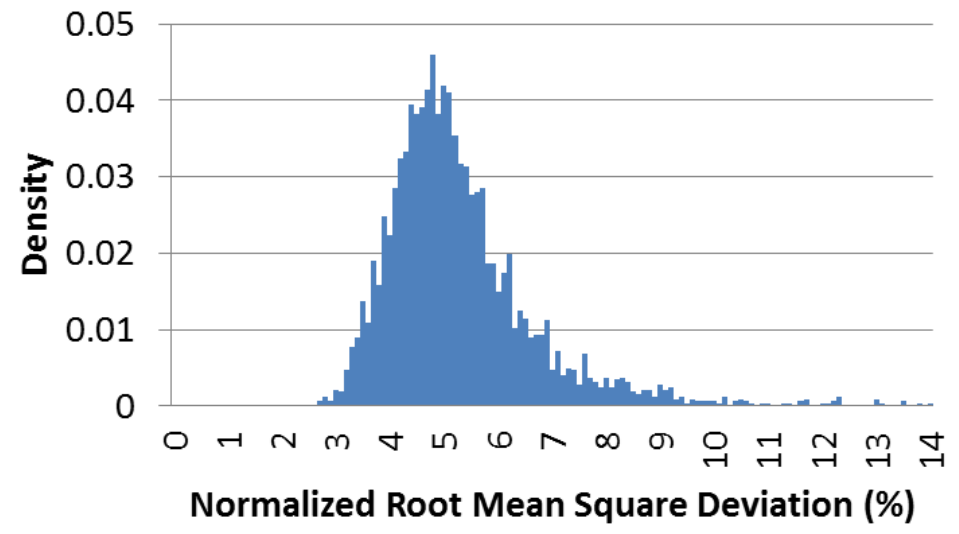

Figure 3. Histograms of the normalized root mean square deviations between distributions of measured wind speeds (from offshore data buoys) and simulated distributions (constructed using the mean, variance, and cross-direction covariance of the measured data) for 288 month-hours at twelve data buoy sites.

As an additional validation step, we compare our tailor-made wind speed distribution against the Weibull distribution with shape parameter $k=2$. To our surprise we find the two distributions to be identical. This unexpected outcome can be derived using the relationships between univariate distributions as discussed in Leemis and McQueston (2008). We find this outcome to be mathematically interesting, but unfortunate given our attempt to move beyond the standard Weibull assumption. For a future analysis we would propose extracting the wind speed distributions directly from the mesoscale modeling outputs rather than estimating them from summary statistics.

\subsection{Scaling Wind Speeds to Hub Height}

According to a recent wind technology analysis from the U.S. Department of Energy, current terrestrial and offshore wind turbines have 80 and 90 meter hub heights on average (US DOE 2015). For this study, we assume wind both terrestrial and offshore turbines have a $90 \mathrm{~m} \mathrm{hub}$ height.

To approximate the distribution of wind speeds at 90m AGL, we linearly interpolate between the distributions derived for $58 \mathrm{~m}$ and $115 \mathrm{~m}$ AGL. In addition to this interpolation method, we also explore the log wind profile and wind profile power law with data from both the $16 \mathrm{~m}$ and $58 \mathrm{~m}$ AGL as the reference height for scaling. However, we find that the wind speeds extrapolated to 90m can often exceed the CFDDA-derived wind speeds at 115m AGL. Figure 4 shows the distribution of wind speed data (represented by gray dots) at the four heights $(16 \mathrm{~m}, 58 \mathrm{~m}, 115 \mathrm{~m}$, 
and $179 \mathrm{~m} \mathrm{AGL)} \mathrm{for} \mathrm{each} \mathrm{the} 288$ month-hours from ten sample offshore wind resource sites (i.e., CFDDA sites) near selected countries (see Figure 5). ${ }^{5}$

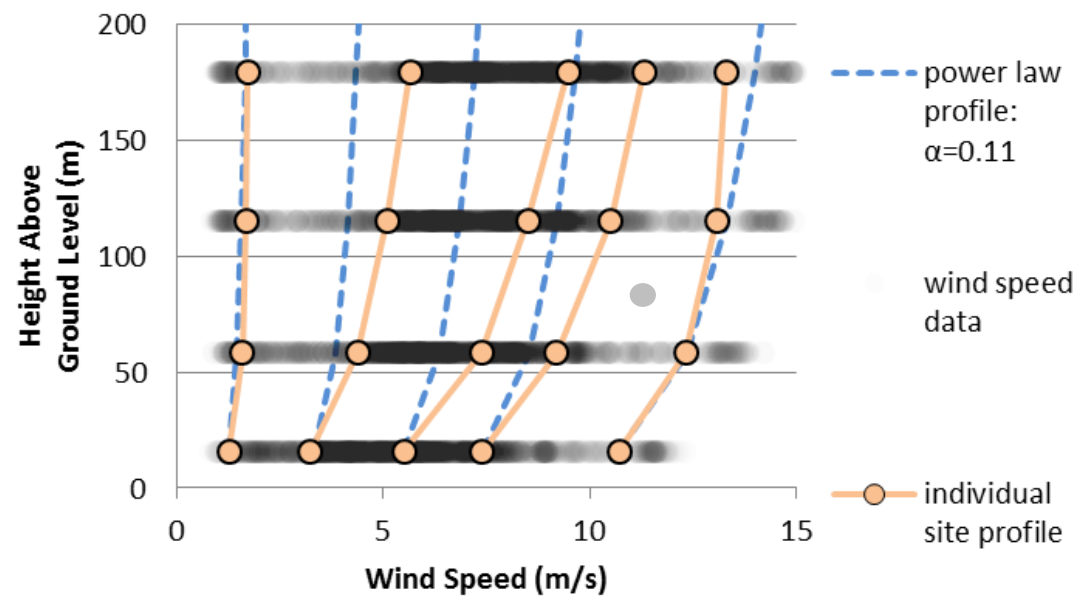

Figure 4. Estimating wind speeds at a $90 \mathrm{~m}$ hub height based on extrapolation up from $10 \mathrm{~m}$ using the power law with a scaling exponent $\alpha=0.11$ (dashed blue lines) versus interpolation between modeled wind speeds at $58 \mathrm{~m}$ and $115 \mathrm{~m}$ (solid orange lines). The gray dots represent modeled wind speeds data for every month-hour at each site and height above ground level.

In Figure 4, we highlight five samples of speed/height relationships derived through the interpolation assumption used in this analysis - represented by solid orange lines — vis-à-vis the power law assumption used in Arent et al. (2012) —represented by dashed blue lines. ${ }^{6}$ Based on the visual comparison in Figure 4, we note that interpolation provides wind speed approximations at 90m AGL that scale more accurately to modeled wind speeds from neighboring heights (58m and $115 \mathrm{~m} \mathrm{AGL}$ ); however, there are instance where the power law profile is similar to the interpolation method at heights up to $115 \mathrm{~m}$ AGL. For a more comprehensive comparison of these methods, we estimate the NRMSD between interpolation and the power law for the 288 month-hours at the ten sample sites noting that the deviation increases at higher heights: $5.4 \%$ at $58 \mathrm{~m} ; 8.2 \%$ at $115 \mathrm{~m}$; and $10.2 \%$ at $175 \mathrm{~m}$ AGL. For a future analysis, we would improve the interpolation between heights using a wind profile power law by processing the wind speeds at various heights to develop a function to describe the relationship between heights.

\footnotetext{
${ }^{5}$ These selected countries are those with larger economies and substantial wind resource, including, Argentina, Australia, Brazil, Canada, China, Denmark, Russia, South Africa, United Kingdom, and United States. We reference these countries elsewhere in this analysis to showcase a subset of results.

${ }^{6}$ Arent et al. (2012) use a scaling exponent $\alpha=0.11$.
} 


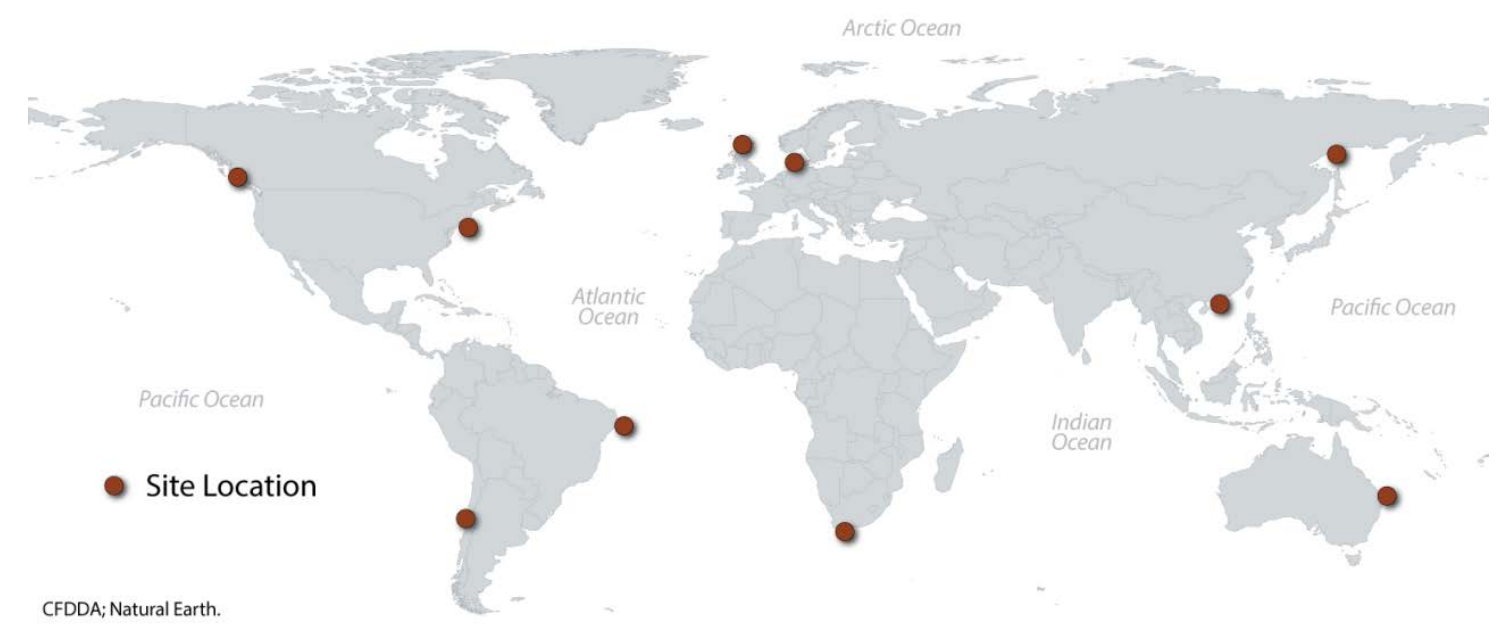

Figure 5. Locations of ten sample offshore CFDDA sites from which we use wind speeds data to compare two methods for estimating wind speeds at a 90m hub height: (1) based on extrapolation up from $16 \mathrm{~m}$ AGL using the power law with a scaling exponent $\alpha=0.11$; (2) interpolation between modeled wind speeds at $58 \mathrm{~m}$ and $115 \mathrm{~m}$.

\subsection{Wind Turbine Power Curve}

Converting the gridded wind speed distributions to estimates of annual energy output requires an assumption of a wind turbine power curve. We assume a 3.5 MW International Electrotechnical Commission (IEC) class I and II composite wind turbine power curve for offshore and terrestrial wind sites, respectively. The U.S. Department of Energy uses these composite IEC turbines for an analysis of wind technical potential for the United States (US DOE 2015). The IEC class I and II power curves, intended to represent an average turbine for a moderate wind climate, are a composite of three commercial turbines - from General Electric, Vestas, and Gamesa. For a future analysis, we would include IEC class III turbine for low-speed sites ${ }^{7}$ as well as allow for dynamic turbine selection based on the wind regime and IEC61400-1 (2005) design parameters. The two representative power curves are shown in Figure 6.

${ }^{7}$ Note that IEC class III turbines are designed specifically for low wind speed regimes and would not be suitable high-speed sites. 


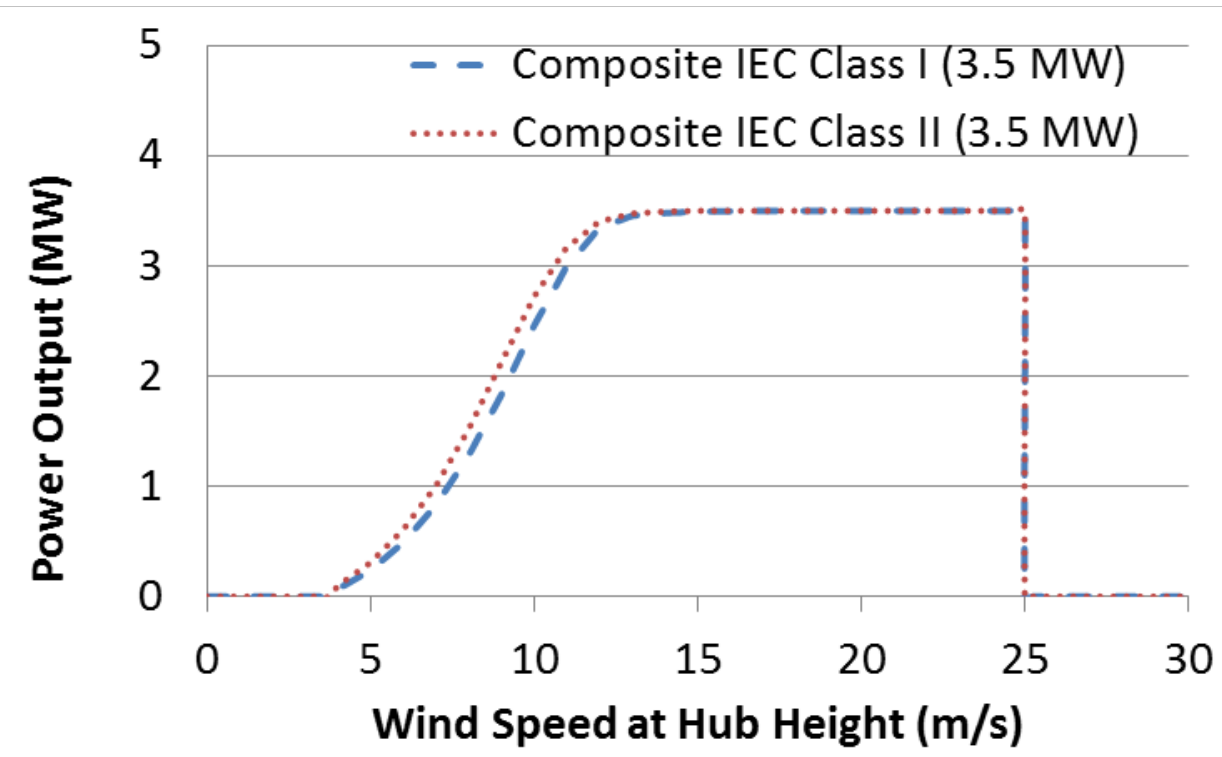

Figure 6. Representative power curve for IEC class I and II composite turbines.

\subsection{Power Curve Adjustment for Altitude}

The power curves for these representative turbines reflect turbine performance at a reference air density - that is, air density at sea level. Because air density and therefore wind power density decrease with elevation, we adjust the reference turbine power output for elevation based on established methods.

Using the methodology in Elliott et al. (1987), we estimate air density $\rho_{i}$ for each CFDDA site $\boldsymbol{i}$ as a function of site altitude $Z_{i}$ (Equation 1). ${ }^{8}$ The elevations are estimated based on the average elevation of Global 30 Arc-Second Elevation data points within the CFDDA site. ${ }^{9}$

$$
\rho_{i}=1.225-1.194 \times 10^{-4} \cdot \mathrm{Z}_{\mathrm{i}}
$$

In general, the theoretical extractable power $P$ of wind at air density $\rho$ moving at a speed $v$ through a wind turbine with swept area $A$ and coefficient of performance $C_{p}$ is:

$$
P=C_{p} \cdot \frac{1}{2} \cdot \rho \cdot A \cdot v^{3}
$$

Based on IEC61400-12-1 (2005), a pitch controlled wind turbine will be able to maintain the same peak power output at different altitudes (shifting the power curve to the left or right). Therefore, we can say that power output at reference air density $P_{\text {ref }}$ will be equal to the power output adjusted for altitude $P_{\text {adj }}$ :

$$
P_{\text {ref }}=P_{a d j}
$$

${ }^{8}$ Although air density is a function of both temperature and pressure which vary by time of day, by season, and by latitude and longitude, we use this simplified estimation of air density due to insufficient temperature and pressure data.

${ }^{9}$ GTOPO30: https://lta.cr.usgs.gov/GTOPO30. Accessed August 30, 2016. 
Next, we calculate the altitude-adjusted wind speed $v_{a d j}$ required to maintain the same maximum power output as the reference wind speed $v_{r e f}$ by substituting equation (2) into both sides of equation (3):

$$
C_{p} \cdot \frac{1}{2} \cdot \rho_{r e f} \cdot A \cdot v_{r e f}{ }^{3}=C_{p} \cdot \frac{1}{2} \cdot \rho_{a d j} \cdot A \cdot v_{a d j}{ }^{3}
$$

Assuming $C_{p}$ is constant with wind speed, we find that:

$$
v_{a d j}=\left(\frac{\rho_{r e f}}{\rho_{a d j}}\right)^{\frac{1}{3}} \cdot v_{r e f}
$$

Svenningsen (2010) notes that assuming a constant coefficient of performance for all wind speeds introduces errors in adjusting a power curve for air density and proposes replacing the $1 / 3$ exponent of the IEC approach by $1 / m$. We adopt this replacement and choose $m$ to vary as a function of wind speed (Figure 7), consistent with Svenningsen. Therefore, Equation (5) becomes:

$$
v_{a d j}=\left(\frac{\rho_{r e f}}{\rho_{a d j}}\right)^{\frac{1}{m}} \cdot v_{r e f}
$$

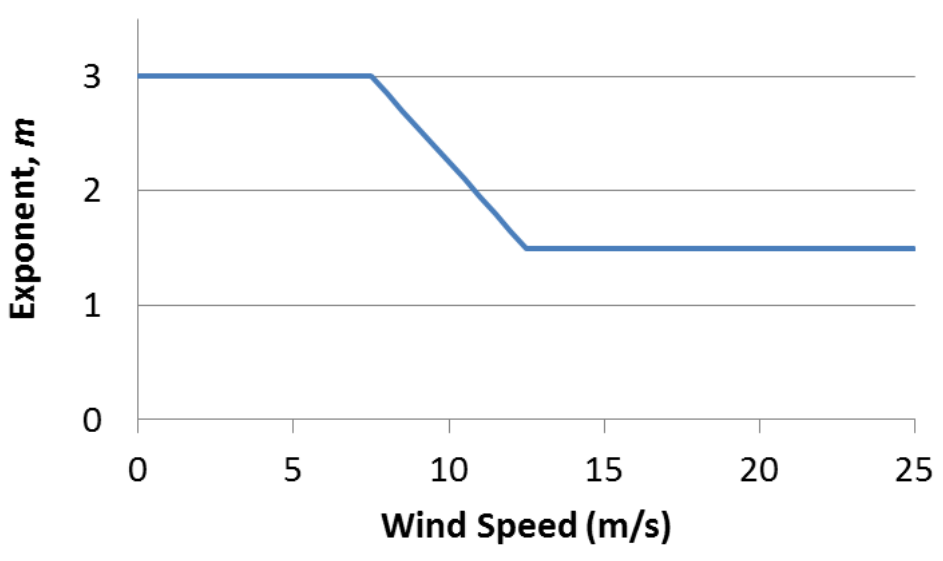

Figure 7. Wind speed adjustment exponent, $m$, as a function of wind speed. This exponent is used in Equation (6) to calculate the speed at which wind must travel within a given air density to yield the same wind turbine power output as wind traveling at a reference speed within a reference air density.

Finally, we resample the altitude-adjusted power outputs at the reference wind speeds $\left(v_{\text {ref }}, P_{a d j}\right)$ to construct the altitude-adjusted power curve. Figure 8 shows an example of an IEC class II power curve that has been adjusted for $25 \%$ lower air density at approximately $2,565 \mathrm{~m}$ above sea level (based on Equation 1); that is, at lower air densities, higher wind speeds are required to achieve the same power output as at the reference air density. 


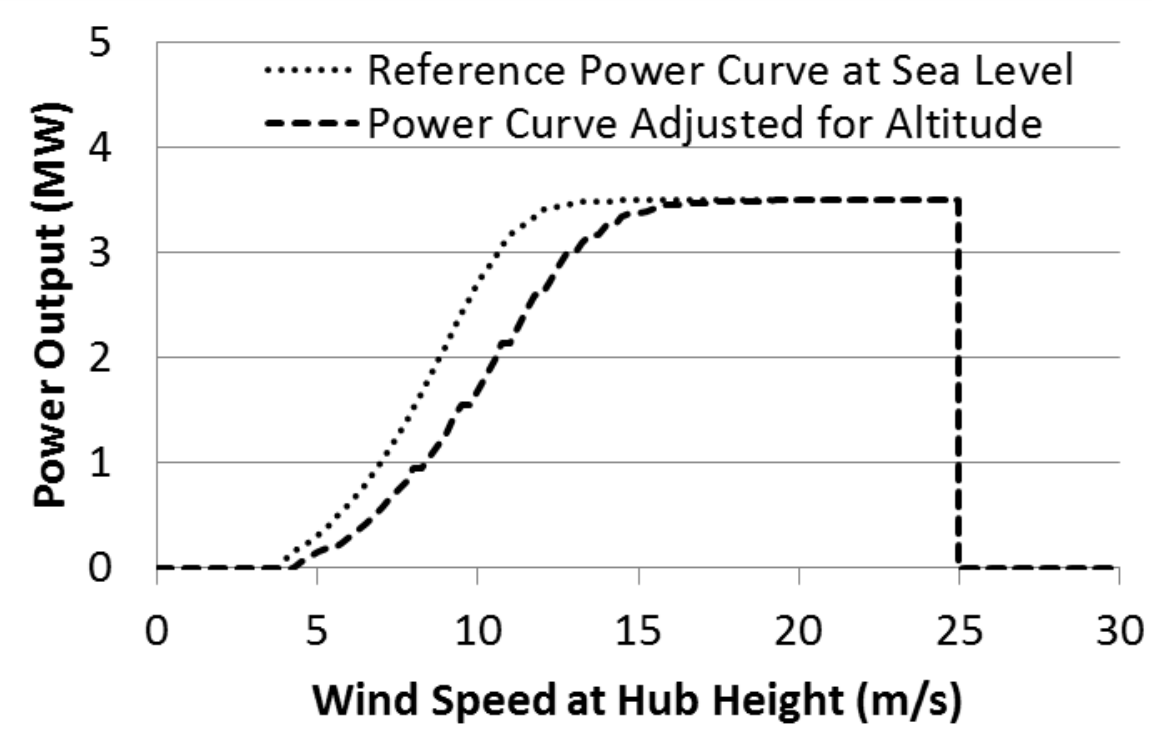

Figure 8. Representative IEC class II turbine power curve adjusted for $25 \%$ lower air density at approximately $2,565 \mathrm{~m}$ above sea level.

\subsection{Wind Energy Output}

Convolving the wind speed distributions with the power curves produces the expected power output $E\left[P_{t, i}\right]$ for month-hour $\boldsymbol{t}$ at site $\boldsymbol{i}$ which we adjust for several effects. To account for the time a turbine will be out of operation due to maintenance and breakdowns, we use an availability $\eta_{\text {avail }}$ of 0.95 (i.e., a turbine loses 5\% of the full-load hours in a year from such outages) based on Hoogwijk et al. (2004). Other turbine power losses result from inevitable interference among individual turbines in a wind farm. Hoogwijk et al. (2004) assume five rotor diameter spacing and a deployment density of $4 \mathrm{MW} / \mathrm{km}^{2}$, corresponding to a turbine array efficiency $\eta_{\text {array }}$ of 0.90 . This array efficiency reflects an estimate that $10 \%$ of potential energy output of from an array is lost to air flow interference (wake losses) on downwind turbines. For this analysis, we assume that wind turbines are spaced in a fixed array: ten rotor diameters apart in the prevailing wind direction and five rotor diameters apart in the cross wind direction; ${ }^{10}$ this corresponds to a deployment density of $5 \mathrm{MW} / \mathrm{km}^{2}$ per Denholm et al. (2009). Based on this deployment density, we use the same 0.9 array efficiency from on Hoogwijk et al. (2004). Applying these losses to the maximum power output, we calculate the net capacity factor $n C F_{t, i}$ for month-hour $\boldsymbol{t}$ at site $\boldsymbol{i}$ :

$$
n C F_{t, i}=\frac{E\left[P_{t, i}\right] \cdot \eta_{\text {avail }} \cdot \eta_{\text {array }}}{P_{\text {rated }}}
$$

Averaging the net capacity factors (nCF) for the 288 month-hours returns an annual average which can be used to classify sites into wind resource regimes. Specifically, we group sites by annual average net capacity factor into 4-percentage-point bins (e.g., 30-34\% nCF). For lowquality resource sites, we place all sites below $18 \% \mathrm{nCF}$ in the lowest bin.

${ }^{10}$ Although the assumed array spacing suggests turbine orientation towards a prevailing wind direction, we do not explicitly consider wind turbine orientation in this analysis. 
Figure 9 shows the annual average net capacity factors for all land area (sans Antarctica) and offshore exclusive economic zones (EEZs) which extend 200 nautical miles off coastlines ${ }^{11}: 90 \mathrm{~m}$ hub height, IEC class I/II turbine (class I for offshore and class II for terrestrial), availability and array efficiency applied. The spatial distribution of capacity factors are well correlated with global wind speed maps - that is, capacity factors are highest in the upper and lower latitudes and lowest near the equator.

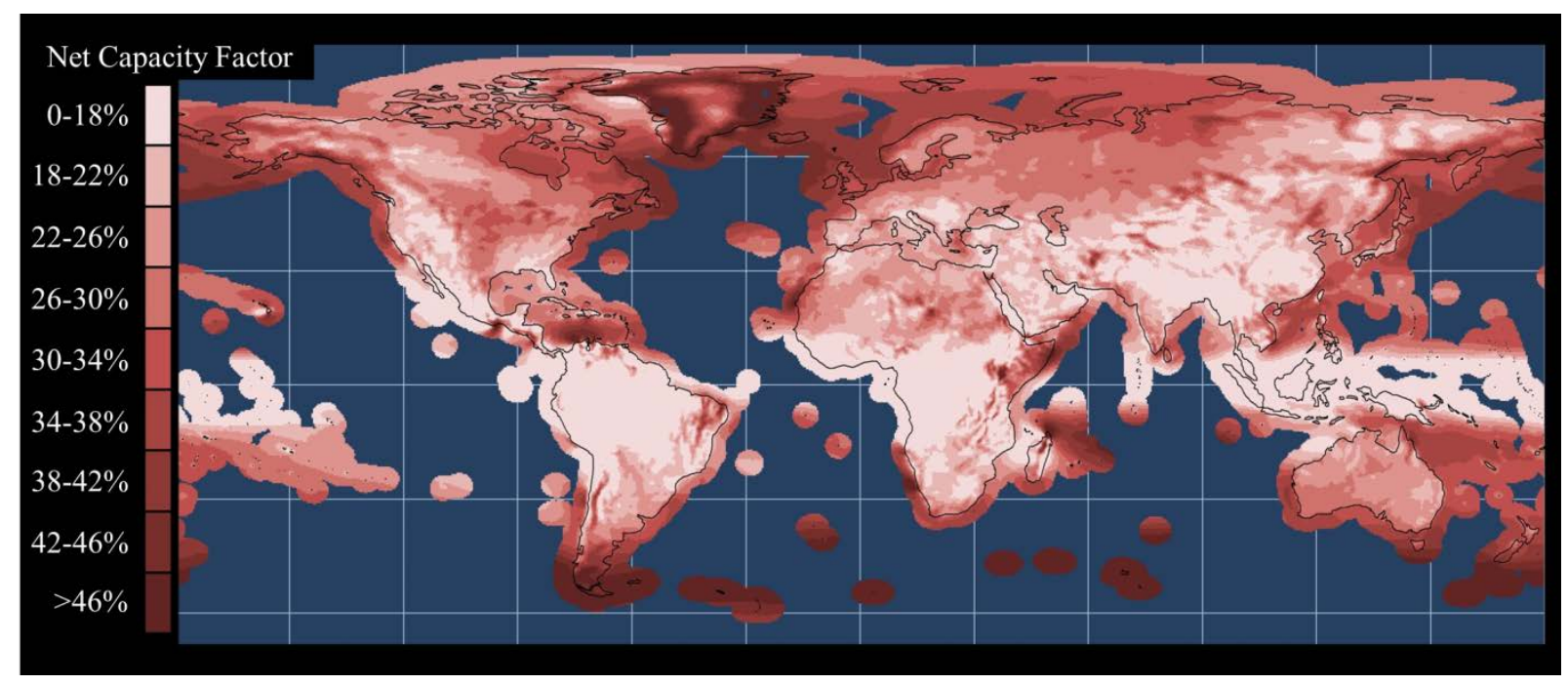

Figure 9. Global annual average net capacity factors (availability and array efficiency included) for land area (sans Antarctica) and offshore area 200 nautical miles from the coastline.

Recent studies have investigated whether the drag from large-scale wind development might reduce wind farm yields worldwide by slowing large-scale winds. Adams and Keith (2013) and Miller et al. (2015) state that wind farm capacity factors are dependent on total wind capacity because large-scale deployment will substantially depress wind speeds beyond local scale. Both references suggest that wind production saturates at a deployment density of $1 \mathrm{MW} / \mathrm{km}^{2}$ and chide global wind resource estimates for assuming much higher densities. For these NREL supply curves we assume a density of $5 \mathrm{MW} / \mathrm{km}^{2}$. We justify not accounting for large-scale wind speed depression in our assumed deployment density because the objective of this work is supply curves to be used by techno-economic energy models, rather than a standard assessment of global wind resource potential. Assuming that wind turbines deployed at $1 \mathrm{MW} / \mathrm{km}^{2}$ over a large area induce negligible wind speed depression effects, the resource estimates in this study can be reduced uniformly by a factor of five to convert from the assumed deployment density of 5 $\mathrm{MW} / \mathrm{km}^{2}$ to $1 \mathrm{MW} / \mathrm{km}^{2}$. For a future analysis, we would use alternative deployment densities based on recent literature to better account for wind speed depression effects of large-scale wind deployment.

\footnotetext{
${ }^{11}$ Although the CFDDA wind resource data extends the full globe, we only process a subset of land and offshore areas that are typically considered in integrated assessment models. For example, Antarctica is ignored due to ice-coverage, harsh climate and minimal electrical load; sea areas beyond 200 nautical miles are ignored because they exceed the EEZ legal regime.
} 


\section{Geographic Classification and Exclusions}

\subsection{Terrestrial Geographic Assumptions}

To construct country-level supply curves, we assign each terrestrial site to its appropriate country. As not all area is available for wind deployment, the wind dataset is combined with geospatial layers of areas unlikely to be developed, such as urban areas, federally protected lands, and inland water features. These geospatial data layers are all represented as $1 \mathrm{~km}$ equal area grid projections. Exclusions are described in Section 3.1.1.

\subsubsection{Terrestrial Exclusions}

Protected areas are mapped to a $1 \mathrm{~km}$ grid using a database by Protected Planet, with areas identified by their International Union for the Conservation of Nature (IUCN) rankings (IUCN and UNEP 2010). We exclude protected areas with IUCN codes of I-III.

According to a study from the International Energy Agency on wind energy projects in cold climate (IEA Wind 2009) permafrost creates challenges for the installation of wind turbines including structural concerns associated with freeze-thaw cycles in the soil. Although wind turbines are being installed in permafrost ${ }^{12}$, we excluded all areas characterized as permafrost using data from the Global Permafrost Zonation Index Map (Gruber 2012). ${ }^{13}$

Air density and therefore wind power density decrease with elevation. As such, we consider areas with elevation greater than 2,500m too high for large-scale wind development using 30 arcsecond $(\sim 1 \mathrm{~km})$ elevation data from the GTOPO30 global digital elevation model. This cutoff is $500 \mathrm{~m}$ higher than the 2,000m maximum altitude assumed by Hoogwijk et al. (2004). For reference, the highest wind turbine in the world built by DeWind in the Andes (Argentina) has a rated capacity of $2 \mathrm{MW}$ and operates at 4,300m serving a remoted electrical load. ${ }^{14}$

We exclude areas with slope greater than 20\%, consistent with Lopez et al. (2012). Slope values are calculated from the GTOPO30 elevation data using the ArcGIS software. ${ }^{15}$

Land use and land cover data are mapped to a $1 \mathrm{~km}$ grid from the GlobCover 2009 Global Land Cover database (Bontemps et al. 2009). Using this dataset, we exclude water areas, permanent snow, and ice - which create both structural and operational challenges associated with cold climates (IEA Wind 2009)_, and urban areas. Similar to the methodology in Hoogwijk et al. (2004), we estimate a suitability factor for each of the remaining GlobCover categories; that is the fraction of land area that is suitable for wind development. We use the suitability factors from Hoogwijk et al. (2004) as the basis for the land-use exclusions. Table 1 summarizes the assumed suitability factor for each GlobCover category.

\footnotetext{
${ }^{12}$ For example, wind turbines have been installed in permafrost areas like Ross Island, Antarctica (Meridian Energy Ltd. 2010) and Kasigluk, Alaska (Dilley and Hulse 2007).

${ }^{13} \mathrm{http}: / /$ www.geo.uzh.ch/microsite/cryodata/pf global/. Accessed August 30, 2016.

$14 \mathrm{http}: / /$ www.dewindco.com/eng/prcenter/record 01.asp. Accessed October 19, 2015.

${ }^{15}$ ArcGIS: https://www.arcgis.com/features/index.html. Accessed August 30, 2016.
} 
Table 1. Suitability factors applied to the GlobCover categories.

\begin{tabular}{|c|c|c|}
\hline $\begin{array}{l}\text { GlobCover } \\
\text { Value }\end{array}$ & GlobCover Category & $\begin{array}{l}\text { Suitability } \\
\text { Factor }^{\text {a }}\end{array}$ \\
\hline 11 & Post-flooding or irrigated croplands & 0 \\
\hline 14 & Rainfed croplands & 0.7 \\
\hline 20 & Mosaic Cropland (50-70\%) / Vegetation (grassland, shrubland, forest) (20-50\%) & 0.7 \\
\hline 30 & Mosaic Vegetation (grassland, shrubland, forest) (50-70\%) / Cropland (20-50\%) & 0.7 \\
\hline 40 & Closed to open ( $>15 \%)$ broadleaved evergreen and/or semi-deciduous forest $(>5 \mathrm{~m})$ & 0.1 \\
\hline 50 & Closed $(>40 \%)$ broadleaved deciduous forest $(>5 \mathrm{~m})$ & 0.1 \\
\hline 60 & Open $(15-40 \%)$ broadleaved deciduous forest $(>5 \mathrm{~m})$ & 0.1 \\
\hline 70 & Closed $(>40 \%)$ needleleaved evergreen forest $(>5 \mathrm{~m})$ & 0.1 \\
\hline 90 & Open $(15-40 \%)$ needleleaved deciduous or evergreen forest $(>5 \mathrm{~m})$ & 0.1 \\
\hline 100 & Closed to open $(>15 \%)$ mixed broadleaved and needleleaved forest $(>5 \mathrm{~m})$ & 0.1 \\
\hline 110 & Mosaic Forest/Shrubland (50-70\%) / Grassland (20-50\%) & 0.5 \\
\hline 120 & Mosaic Grassland (50-70\%) / Forest/Shrubland (20-50\%) & 0.65 \\
\hline 130 & Closed to open $(>15 \%)$ shrubland $(<5 \mathrm{~m})$ & 0.5 \\
\hline 140 & Closed to open $(>15 \%)$ grassland & 0.8 \\
\hline 150 & Sparse (>15\%) vegetation (woody vegetation, shrubs, grassland) & 0.9 \\
\hline 160 & Closed $(>40 \%)$ broadleaved forest regularly flooded - Fresh water & 0 \\
\hline 170 & $\begin{array}{l}\text { Closed ( }>40 \% \text { ) broadleaved semi-deciduous and/or evergreen forest regularly } \\
\text { flooded - Saline water }\end{array}$ & 0 \\
\hline 180 & $\begin{array}{l}\text { Closed to open ( }>15 \%) \text { vegetation (grassland, shrubland, woody vegetation) on } \\
\text { regularly flooded or waterlogged soil - Fresh, brackish or saline water }\end{array}$ & 0 \\
\hline 190 & Artificial surfaces and associated areas (urban areas $>50 \%$ ) & 0 \\
\hline 200 & Bare areas & 0.9 \\
\hline 210 & Water bodies & 0 \\
\hline 220 & Permanent snow and ice & 0 \\
\hline
\end{tabular}

${ }^{\mathrm{a}}$ Derived based on land-use categories and suitability factors from Hoogwijk et al. (2004).

Table 2 summarizes the terrestrial exclusion criteria. Taken together, these geographic exclusions can eliminate substantial land area from the wind resource potential as shown in Figure 10 for selected countries. We apply the exclusions is the following order: (a) Elevation; Slope, (b) Protected Areas, (c) Water (including water bodies, snow, ice, and permafrost), and (d) Land Use Suitability. For example, if "Elevation; Slope" and "Protected Areas" both apply, then we assign the exclusion to "Elevation; Slope". Overall, land-use suitability tends to be one of the largest factors in removing land. ${ }^{16}$ Russia and Canada lose substantial land to permafrost. China loses the Tibetan Plateau due to elevation.

${ }^{16}$ For a future analysis, we would quantify the land use exclusions by GlobCover categories for each country to assess the validity the assumed suitability factors. 
Table 2. Summary of terrestrial exclusions.

\begin{tabular}{lll}
\hline Exclusion Category & Exclusion Criteria & Data Layer Source \\
\cline { 2 - 3 } Protected Areas & $\begin{array}{l}100 \% \text { exclusion for protected areas } \\
\text { with IUCN rankings codes of I-III. }\end{array}$ & $\begin{array}{l}\text { Protected Planet (IUCN and } \\
\text { UNEP 2010) }\end{array}$ \\
\cline { 2 - 3 } Permafrost & $\begin{array}{l}\text { 100\% exclusion for permafrost. } \\
\text { Elevation }\end{array}$ & $\begin{array}{l}\text { Global Permafrost Zonation } \\
\text { Index Map (Gruber 2012) }\end{array}$ \\
\cline { 2 - 3 } Slope & $\begin{array}{l}100 \% \text { exclusion for areas with } \\
\text { elevation greater than 2,500m. }\end{array}$ & $\begin{array}{l}\text { Global 30 Arc-Second Elevation } \\
\text { (GTOPO30) }\end{array}$ \\
\cline { 2 - 3 } & $\begin{array}{l}100 \% \text { exclusion for areas with slope } \\
\text { greater than 20\%. }\end{array}$ & $\begin{array}{l}\text { Calculated from elevation data } \\
\text { in GTOPO30 using ArcGIS. }\end{array}$ \\
\cline { 2 - 3 } & $\begin{array}{l}100 \% \text { exclusion for water areas, } \\
\text { permanent snow and ice, and urban } \\
\text { areas. }\end{array}$ & $\begin{array}{l}\text { GlobCover 2009 (Bontemps et } \\
\text { al. 2009) }\end{array}$ \\
Land Use/Land Cover & $\begin{array}{l}\text { Partial exclusions based on suitability } \\
\text { factors. }\end{array}$ & \\
\hline & & \\
\hline
\end{tabular}

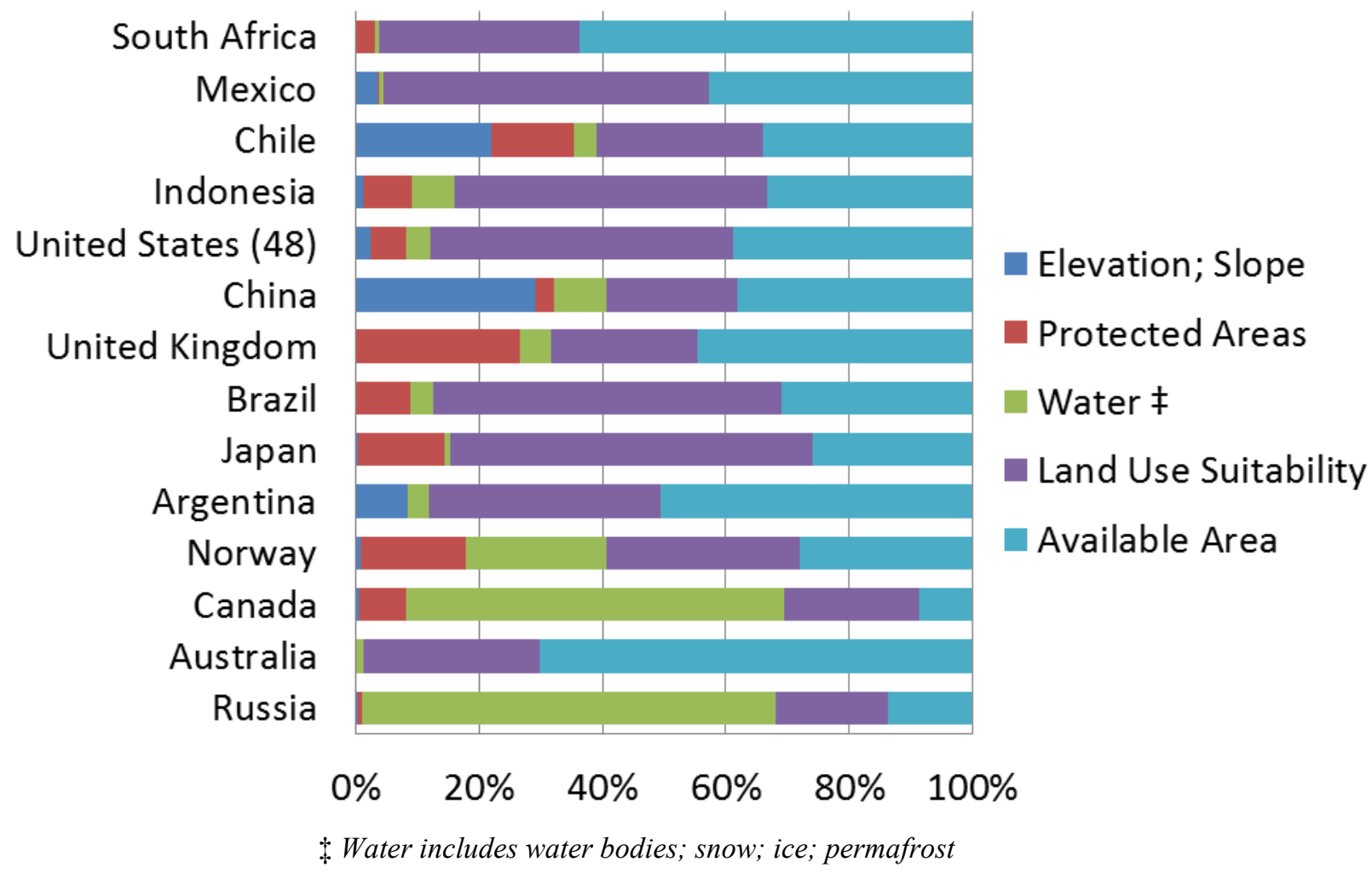

Figure 10. Percentages of land area excluded for selected countries. Exclusions are applied in descending order with respect to the ordering in the legend (e.g., if "Elevation; Slope" and "Protected Areas" both apply, then we assign the exclusion to "Elevation; Slope"). The underlying data are shown in the appendix. 


\subsubsection{Resource Accessibility}

All else being equal, wind resources that exist farther from the transmission network are more expensive to access. In the absence of a consistent global dataset of transmission networks, we approximate accessibility as the distance from the resource site to the nearest large power plant or large city. We use publicly available global data on power plants available through the Carbon Monitoring for Action website ${ }^{17}$ which includes power plant location coordinates, present annual generation, and annual carbon emissions. Large power plants are identified based on the annual generation, limiting the analysis to plants with generation of 200,000 MWh and greater (approximately a $25-\mathrm{MW}$ plant with a $90 \%$ capacity factor). We define large cities as urban areas with populations greater than 50,000 (derived from the LandScan 2011 Global Population Database). ${ }^{18}$

Denser areas - with more cities and power plants - have shorter characteristic distances to transmission lines than less-dense regions. The denser regions, then, will have a higher fraction of their wind potential classified as 'near' to transmission. We classify the accessibility distance as 'near' (0-80 km), 'mid' (80-161 km), and 'far' (greater than $161 \mathrm{~km})$. For context on these distance categories, consider the United States' population and power-plant density (Figure 11). Based on In the Eastern United States, very nearly all of the land area is within $80 \mathrm{~km}$ of a transmission line (see Figure 12), whereas in the less-populated west, a sizeable fraction of the land is more than $80 \mathrm{~km}$ out (and would thus be categorized as 'mid'). Additionally, the vast expanses of wilderness in Alaska results in substantial technical potential; nearly all of it separated from cities and power plants by similarly vast distances.

${ }^{17} \mathrm{http}: / /$ www.carma.org. Accessed August 30, 2016.

18 http://web.ornl.gov/sci/landscan/landscan_data_avail.shtml. Accessed August 30, 2016. 


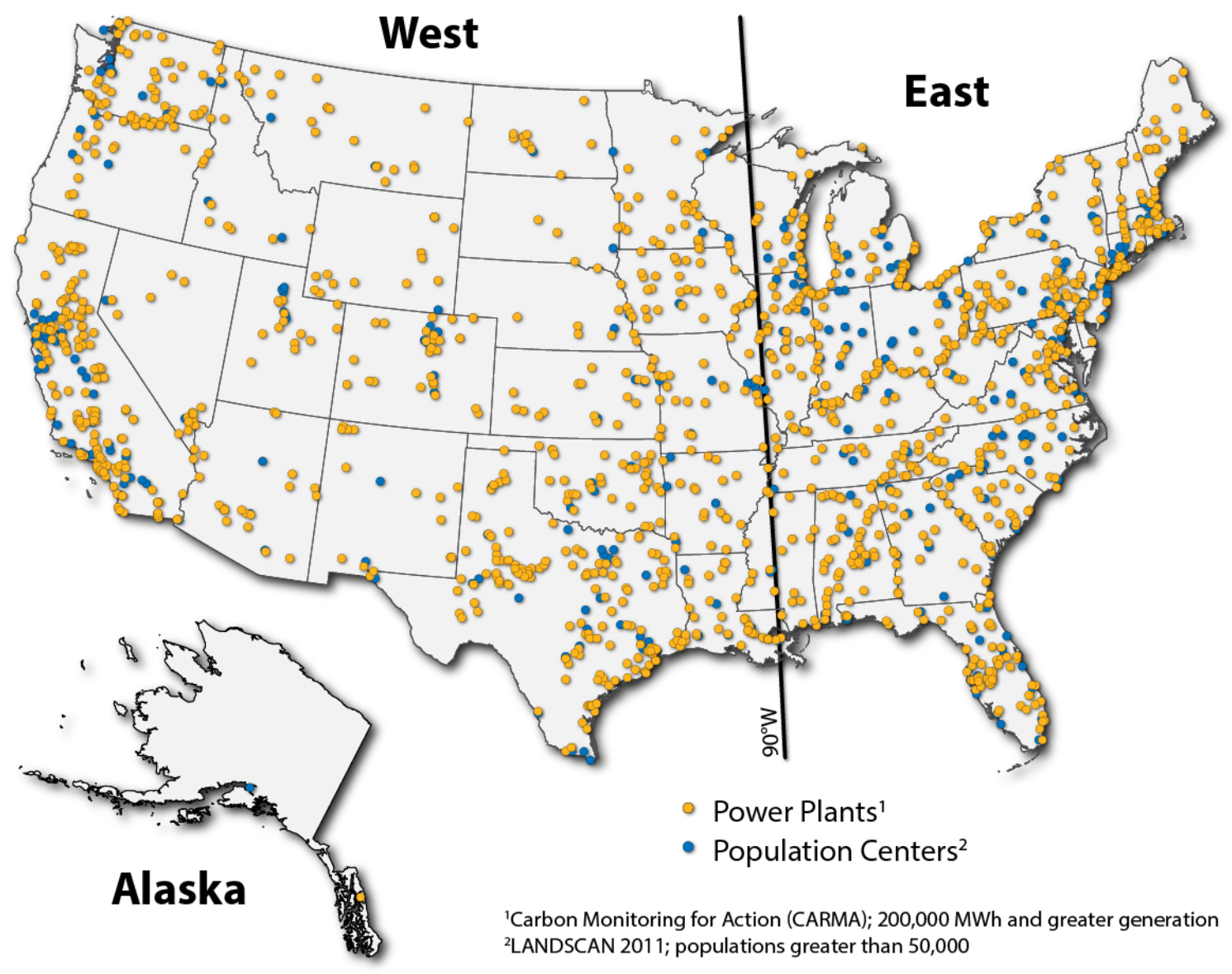

Figure 11. Large power plants and large urban areas in the lower 48 United States and Alaska.

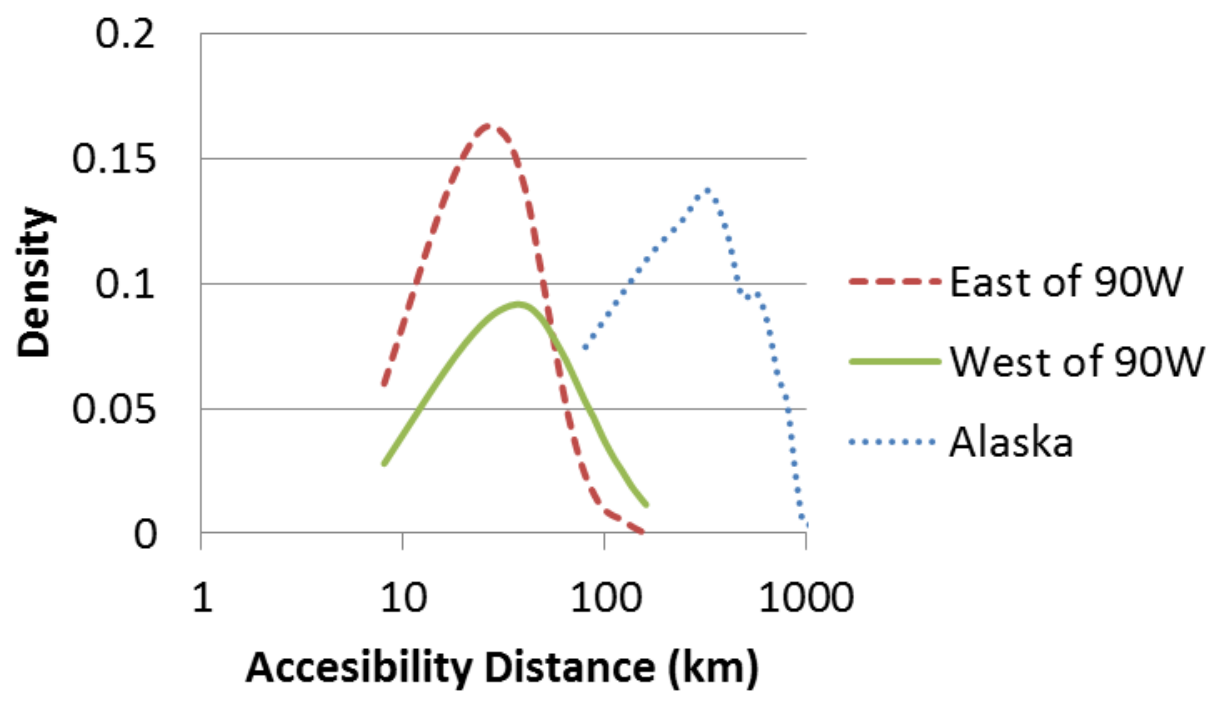

Figure 12. Distributions of accessibility distances for U.S. wind resource sites to the east and west of the Mississippi River (approximated using $90^{\circ} \mathrm{W}$ ) and Alaska. 


\subsection{Offshore Geographic Assumptions}

In order to assign offshore resource to countries, we use the Flanders Marine Institute Maritime Boundaries Geodatabase to define EEZs for offshore regions. Legal EEZs extend up to 200 nautical miles from the coastline. Using the World Wildlife Federation Global Lakes and Wetlands Database, ${ }^{19}$ we append the offshore spatial extent with large lakes (over $3,000 \mathrm{~km}^{2}$ ) that are not classified under any EEZ. As with terrestrial resource, we exclude area unlikely to be developed such as marine protected areas and sea ice. These geospatial data layers are all represented as $2 \mathrm{~km}$ equal area grid projections. The offshore exclusions are detailed in Sections 3.2.1-3.2.3.

\subsubsection{Marine Protected Areas}

Marine conservation areas are mapped to a $2 \mathrm{~km}$ grid using a database by Protected Planet (IUCN and UNEP 2010), with areas identified by their IUCN rankings. We exclude protected areas with IUCN codes of I-III.

\subsubsection{Sea Ice Exclusions}

Within the realm of offshore wind resource assessments, there is limited focus on sea-ice exclusions. Arent et al. (2012) assume missing wind speed data for certain months in northern latitudes to be ice-caused, but do not explicitly exclude areas due to sea ice. Lu et al. (2009) account for ice-cover for terrestrial wind, but do not reference sea-ice for offshore. Deng et al. (2015) account for sea-ice, but exclusions are limited to simple polar latitude cutoffs.

For polar latitudes, we seek an exclusion layer for areas challenging to develop because of extensive sea-ice cover that can cause, for example, added static and dynamic forces to the wind turbine tower structure (Battisti et al. 2006). Starting from the definition of ice extent as the cumulative area of sites having calculated sea ice concentrations of at least 15\% (Parkinson et al. 1999), we select $15 \%$ as our ice cover threshold. Using arctic ice cover data from the National Snow and Ice Data Center ${ }^{20}$ and Great Lakes ice cover data from the National Oceanic and Atmospheric Administration, ${ }^{21}$ we chart the median and maximum ice concentration on a $2 \mathrm{~km}$ grid for a given month over the years 2003-2007. Then we tag each site with the number of months per year it is within the ice extent for both the median and maximum concentration. Based on the months of ice cover at locations of planned wind-site developments (Table 3 ) in the Bay of Bothnia ${ }^{22}$ - between Sweden and Finland - we chose to use eight months as our exclusion threshold: we exclude sites that spend more than eight months of an average year with median sea ice concentration of at least $15 \%$.

${ }^{19} \mathrm{https}: / /$ www.worldwildlife.org/pages/global-lakes-and-wetlands-database. Accessed August $30,2016$.

20"National Ice Center Arctic Sea Ice Charts and Climatologies in Gridded Format": http://nsidc.org/data/docs/noaa/g02172 nic_charts_climo_grid/index.html. Accessed August 30, 2016.

21 "NOAA Great Lakes Ice Atlas": http://www.glerl.noaa.gov/data/ice/atlas/daily ice cover/daily grids/dailygrids.html. Accessed August 30, 2016.

${ }^{22}$ Data for proposed wind projects are sourced from the 4C Offshore windfarm database: http://www.4coffshore.com/windfarms/. Accessed April 4, 2013. 
Table 3. Proposed offshore wind projects in the Bay of Bothnia.

\begin{tabular}{llcc}
\hline Project Name & Status & $\begin{array}{l}\text { Months of Ice Cover } \\
\text { (Based on Median } \\
\text { Concentration) }\end{array}$ & $\begin{array}{l}\text { Months of Ice Cover } \\
\text { (Based on Max } \\
\text { Concentration) }\end{array}$ \\
\cline { 2 - 4 } Oulun-Haukiputaan alue 2 & Consent Application Submitted & 5 & 6 \\
Oulun-Haukiputaan alue 1 & Consent Application Submitted & 5 & 6 \\
Kemi Ajos III & Concept/Early Planning & 5 & 6 \\
Suurheikka & Consent Authorized & 4 & 6 \\
Tornio & Consent Application Submitted & 5 & 7 \\
Klocktärnan & Concept/Early Planning & 4 & 6 \\
\hline
\end{tabular}

According to Lantuit et al. (2012), arctic coastlines, which represent $34 \%$ of global coastlines, are affected by both sea ice and permafrost. For this analysis, we do not explicitly consider coastal permafrost exclusions for offshore wind development. However, we anticipate some overlap of permafrost areas with areas excluded due to sea ice and/or with areas excluded due to proximity to shore, i.e., within 5 nautical miles, as discussed in Section 3.2.3. For a future analysis, we would attempt to capture coastline permafrost exclusions.

\subsubsection{Water Depth and Distance to Shore}

We classified remaining marine area by water depth (relative to sea level) and distance to shore: depth because different - generally, more expensive - mooring infrastructure can be required for turbines sited in deeper water; distance-to-shore because increased distance can be associated with higher cost to connect to transmission. For bathymetry, we used the ETOPO1 1 Arc-Minute Global Relief Model 3 to estimate water depth for a $2 \mathrm{~km}$ grid. ${ }^{23}$ We defined the depth classes to correspond to those used by Musial and Ram (2010): shallow (0-30m), transitional (30-60m), and deep $(60-1,000 \mathrm{~m})$. We exclude resource in areas that are greater than 1,000 meters in depth. Consistent with Musial and Ram (2010) and US DOE (2015), these depth classifications imply monopole construction for shallow; jacket structures or multi-pile foundations for transitional; and floating technology for deep.

For distance-to-shore, we excluded all area within five nautical miles $(\mathrm{nm})$ of shore as a coarse application of public resistance to visual disturbance and environmental concern based on Musial and Butterfield (2004).

Within the maritime EEZs, we classified remaining area as near $(5-20 \mathrm{~nm})$, intermediate (20-50 $\mathrm{nm})$, or far $(50-100 \mathrm{~nm})$ to shore. Area beyond 100 nautical miles to shore is deemed too far for offshore wind development. The distance-to-shore metric does not account for the distance to connect from the shore to the electric power grid. For a future analysis, we would include for this shore-to-grid distance in order to have and more complete accessibility metric for offshore wind.

Table 4 summarizes the offshore exclusions criteria. In Figure 13, we showcase these exclusions for selected EEZs, applying them in the following order: (a) Distance to Shore, (b) Protected Areas, (c) Water Depth, and (d) Sea Ice. For example, if "Distance to Shore" and "Protected Areas" both apply, then we assign the exclusion to "Distance to Shore" for selected EEZs.

${ }^{23}$ The ETOPO1 Global Relief Model (1 arc-minute resolution) distributed by NOAA: http://www.ngdc.noaa.gov/mgg/global/global.html. Accessed March 13, 2013. 
Overall, distance-to-shore and water-depth tend to be the largest factors in removing water area. Russia and Canada lose substantial area to sea ice.

Table 4. Summary of offshore wind exclusions.

\begin{tabular}{lll}
\hline Exclusion Category & Exclusion Criteria & Data Source \\
\cline { 2 - 3 } Protected Areas & $\begin{array}{l}\text { 100\% exclusion for protected areas with } \\
\text { IUCN rankings codes of I-III. }\end{array}$ & $\begin{array}{l}\text { Protected Planet (IUCN and } \\
\text { UNEP 2010) }\end{array}$ \\
\cline { 2 - 3 } Sea Ice & $\begin{array}{l}100 \% \text { exclusion for areas with 8 months } \\
\text { of ice cover (15\% cutoff; based on } \\
\text { median ice concentration). }\end{array}$ & NSIDC - arctic sea ice \\
\cline { 2 - 3 } Distance to Shore & $\begin{array}{l}\text { Minimum distance of 5 nautical miles. } \\
\text { Maximum distance of 100 nautical miles. }\end{array}$ & $\begin{array}{l}\text { Calculated based on } \\
\text { geospatial analysis. }\end{array}$ \\
\cline { 2 - 3 } Water Depth & $\begin{array}{l}\text { 100\% exclusion for areas with water } \\
\text { depth }>1000 \mathrm{~m} .\end{array}$ & $\begin{array}{l}\text { ETOPO1 1 Arc-Minute } \\
\text { Global Relief Model3 }\end{array}$ \\
\hline
\end{tabular}

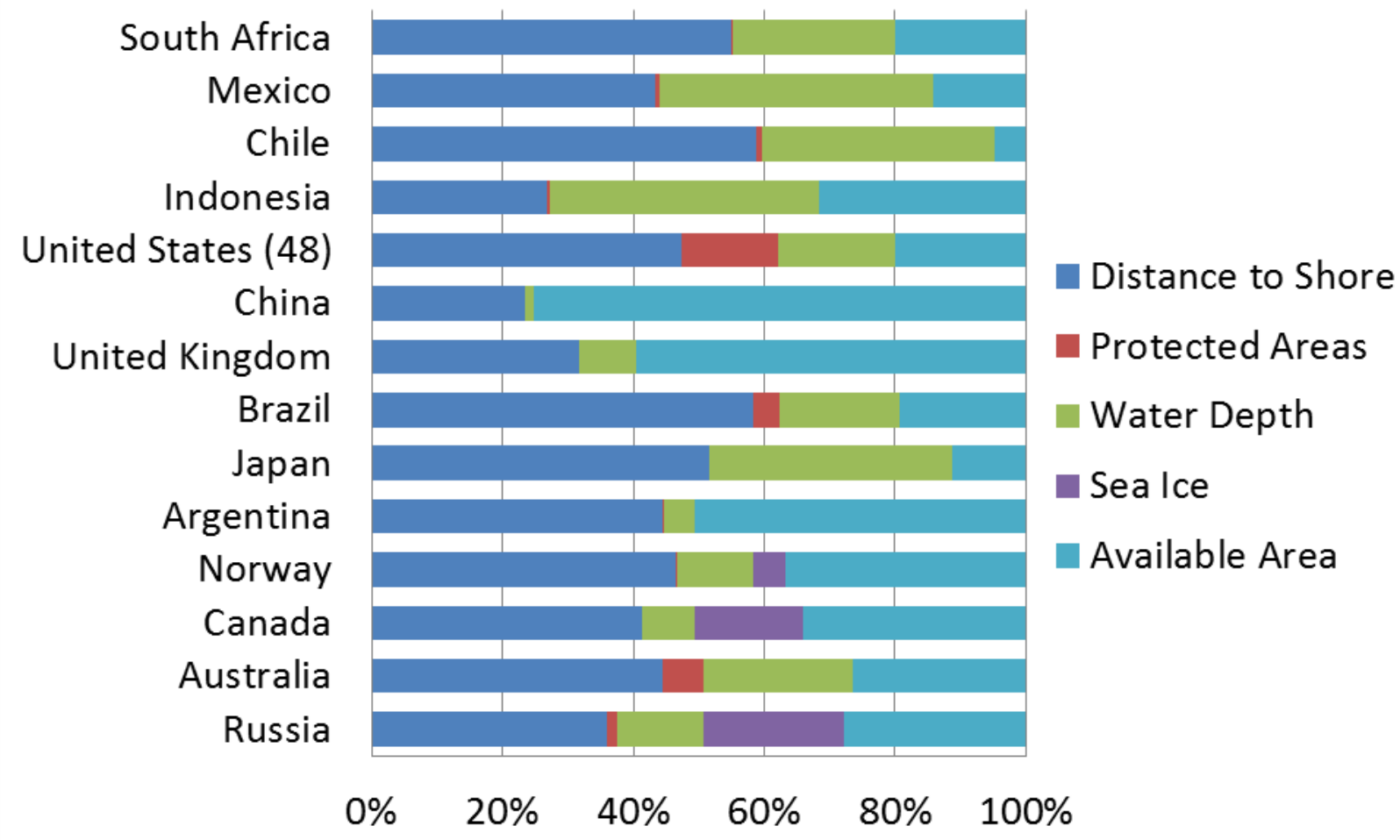

Figure 13. Percentages of water area excluded for selected EEZs. Exclusions are applied in descending order with respect to the ordering in the legend (e.g., if "Distance to Shore" and "Protected Areas" both apply, then we assign the exclusion to "Distance to Shore"). The underlying data are shown in the appendix. 


\section{Technical Potential}

Technical potential is measured in terms of wind capacity and generation that is available with consideration for system/topographical constraints, land-use constraints, and system performance (Lopez et al. 2012). Using the geographic exclusion layers (Section 3), we determine the available area for wind turbine deployment. Then we calculate the capacity potential $\operatorname{Pot}_{i}^{\text {cap }}$ in each site $\boldsymbol{i}$ as a function of turbine deployment density $\delta$ and total available land area $A_{i}^{\text {avail }}$ :

$$
\operatorname{Pot}_{i}^{\text {cap }}=\delta \cdot A_{i}^{\text {avail }}
$$

Using the capacity potential and annual average net capacity factors (Section 2), we calculate the annual generation potential $P o t_{i}^{g e n}$ for each site $\boldsymbol{i}$ as a function of capacity potential and the number of equivalent full-load hours:

$$
\operatorname{Pot}_{i}^{g e n}=\operatorname{Pot}_{i}^{c a p} \cdot 8760 \cdot n C F
$$




\section{Results}

The global generation potential totals $560 \mathrm{PWh}$ for terrestrial wind and $315 \mathrm{PWh}$ for offshore wind. These estimates are based on 3.5 MW IEC class II (terrestrial) and I (offshore) composite wind turbines with $90 \mathrm{~m}$ hub heights, $95 \%$ availability, $90 \%$ array efficiency, and $5 \mathrm{MW} / \mathrm{km}^{2}$ deployment density in non-excluded areas. In this section, we delineate the resource potential by region, resource quality, and accessibility. ${ }^{24}$

Table 5 and Table 6 give the distribution of the resource potential based on wind quality. We categorize net capacity factor into nine classes: the lowest quality resource is placed in class 1 (below 18\% nCF); the highest quality in class 9 (above $46 \% \mathrm{nCF}$ ); and the remainder in classes 2-8 in four-percentage-point bins. The terrestrial generation potential is weighted towards lowto-mid quality with classes $1-4(0-30 \% \mathrm{nCF})$ constituting $90 \%$ of the total $560 \mathrm{PWh}$ and $17 \%$ in class $1(0-18 \% \mathrm{nCF})$ alone. By comparison, offshore wind generation potential is weighted towards mid-to-high quality with classes 5-6 (30-38\% nCF) constituting 42\% of the total 315 PWh and classes 4-7 (26-42\% nCF) constituting 67\%.

Table 5. Global terrestrial wind generation potential by resource class.

\begin{tabular}{lrr}
\hline $\begin{array}{c}\text { Terrestrial Wind } \\
\text { Resource Class }\end{array}$ & $\begin{array}{r}\text { Generation Potential } \\
(\text { PWh) }\end{array}$ & $\begin{array}{r}\text { \%of Total } \\
\text { Resource }\end{array}$ \\
\cline { 2 - 3 } Class $1: 0-0.18 \mathrm{nCF}$ & 95.06 & 17.1 \\
Class $2: 0.18-0.22$ & 129.14 & 23.2 \\
Class $3: 0.22-0.26$ & 165.13 & 29.6 \\
Class $4: 0.26-0.3$ & 111.97 & 20.1 \\
Class $5: 0.3-0.34$ & 29.54 & 5.3 \\
Class $6: 0.34-0.38$ & 12.98 & 2.3 \\
Class $7: 0.38-0.42$ & 7.26 & 1.3 \\
Class $8: 0.42-0.46$ & 3.34 & 0.6 \\
Class $9: 0.46-1.0$ & 3.08 & 0.6 \\
& $\mathbf{5 5 7 . 4 9}$ & \\
\hline
\end{tabular}

Table 6. Global offshore wind generation potential by resource class.

\begin{tabular}{lrr}
\hline $\begin{array}{r}\text { Offshore Wind } \\
\text { Resource Class }\end{array}$ & $\begin{array}{r}\text { Generation Potential } \\
\text { (PWh) }\end{array}$ & $\begin{array}{r}\text { \%of Total } \\
\text { Resource }\end{array}$ \\
\cline { 2 - 3 } Class $1: 0-0.18$ nCF & 21.72 & 6.9 \\
Class $2: 0.18-0.22$ & 18.26 & 5.8 \\
Class $3: 0.22-0.26$ & 26.67 & 8.5 \\
Class $4: 0.26-0.3$ & 35.78 & 11.4 \\
Class $5: 0.3-0.34$ & 64.04 & 20.3 \\
Class $6: 0.34-0.38$ & 67.37 & 21.4 \\
Class $7: 0.38-0.42$ & 43.02 & 13.7 \\
Class $8: 0.42-0.46$ & 16.13 & 5.1 \\
Class $9: 0.46-1.0$ & 21.80 & 6.9 \\
\hline
\end{tabular}

${ }^{24}$ The complete supply curves can be downloaded from https://catalog.data.gov/dataset/globalcfdda-based-onshore-and-offshore-wind-potential-supply-curves-by-country-class-and--67676. Accessed August 30, 2016. 
Table 7 and Table 8 give a regional breakdown of the wind technical potential for a subset of geographical areas (countries for terrestrial and EEZs for offshore). These geographical areas have generally larger economies with substantial wind resource. Notice that the capacity and generation potential are not necessarily correlated as the distribution of resource quality varies by location.

Table 7. Regional breakdown of total area, available area, and technical potential for terrestrial wind in selected countries.

\begin{tabular}{lrrrrr}
\hline \multirow{2}{*}{ Country } & $\begin{array}{r}\text { Total Land } \\
\text { Area } \mathbf{( k m}^{\mathbf{2}} \mathbf{a}^{\mathbf{a}}\end{array}$ & $\begin{array}{r}\text { Available } \\
\text { Land Area } \\
\mathbf{( k m}^{\mathbf{2}} \mathbf{a}^{\mathbf{a}}\end{array}$ & $\begin{array}{r}\text { \% Land } \\
\text { Area } \\
\text { Available }\end{array}$ & $\begin{array}{r}\text { Terrestrial } \\
\text { Wind Capacity } \\
\text { Potential } \\
\text { (TW) }\end{array}$ & $\begin{array}{r}\text { Terrestrial Wind } \\
\text { Generation } \\
\text { Potential } \\
\text { (PWh/yr) }\end{array}$ \\
\cline { 2 - 6 } Aussia & $18,488,000$ & $2,529,000$ & $14 \%$ & 12.64 & 29.57 \\
Canada & $8,426,000$ & $5,902,000$ & $70 \%$ & 29.51 & 63.97 \\
Norway & $10,707,000$ & 912,000 & $9 \%$ & 4.56 & 10.55 \\
Argentina & 328,000 & 91,000 & $28 \%$ & 0.46 & 1.32 \\
Japan & $3,066,000$ & $1,550,000$ & $51 \%$ & 7.75 & 17.90 \\
Brazil & 361,000 & 94,000 & $26 \%$ & 0.47 & 1.00 \\
United Kingdom & $9,407,000$ & $2,917,000$ & $31 \%$ & 14.58 & 22.22 \\
China & 236,000 & 105,000 & $44 \%$ & 0.53 & 1.60 \\
United States (48) & $10,369,000$ & $3,962,000$ & $38 \%$ & 19.81 & 32.50 \\
Indonesia & $8,757,000$ & $3,390,000$ & $39 \%$ & 16.95 & 36.13 \\
Chile & $1,883,000$ & 627,000 & $33 \%$ & 3.14 & 2.07 \\
Mexico & 763,000 & 259,000 & $34 \%$ & 1.29 & 2.08 \\
South Africa & $2,117,000$ & 906,000 & $43 \%$ & 4.53 & 6.88 \\
Global & $1,345,000$ & 858,000 & $64 \%$ & 4.29 & 7.76 \\
\hline C Country & $\mathbf{1 4 6 , 7 0 4 , 0 0 0}$ & $\mathbf{5 9 , 6 6 5 , 0 0 0}$ & $\mathbf{4 1 \%}$ & $\mathbf{2 9 8}$ & $\mathbf{5 5 7}$ \\
\hline
\end{tabular}

${ }^{\mathrm{a}}$ Country total and available land area is estimated based on $1 \mathrm{~km}$ equal area grid projections. Values have been rounded to the nearest thousands. 
Table 8. Regional breakdown of total area, available area, and technical potential for offshore wind in selected EEZs.

\begin{tabular}{|c|c|c|c|c|c|}
\hline EEZ & $\begin{array}{r}\text { Total EEZ } \\
\text { Area }\left(\mathbf{k m}^{2}\right)^{\mathrm{a}}\end{array}$ & $\begin{array}{r}\text { Available } \\
\text { EEZ Area } \\
\left(\mathbf{k m}^{2}\right)^{\mathrm{a}}\end{array}$ & $\begin{array}{r}\% \text { EEZ } \\
\text { Area } \\
\text { Available }\end{array}$ & $\begin{array}{r}\text { Offshore Wind } \\
\text { Capacity } \\
\text { Potential } \\
(\mathrm{TW})\end{array}$ & $\begin{array}{r}\text { Offshore Wind } \\
\text { Generation } \\
\text { Potential } \\
(\text { PWh/yr })\end{array}$ \\
\hline Russia & $8,337,000$ & $2,311,000$ & $28 \%$ & 11.55 & 34.26 \\
\hline Australia & $7,695,000$ & $2,032,000$ & $26 \%$ & 10.16 & 24.60 \\
\hline Canada & $6,275,000$ & $2,136,000$ & $34 \%$ & 10.68 & 33.51 \\
\hline Norway & $1,953,000$ & 718,000 & $37 \%$ & 3.59 & 11.33 \\
\hline Argentina & $1,198,000$ & 606,000 & $51 \%$ & 3.03 & 10.34 \\
\hline Japan & $4,469,000$ & 500,000 & $11 \%$ & 2.50 & 6.36 \\
\hline Brazil & $3,533,000$ & 686,000 & $19 \%$ & 3.43 & 7.04 \\
\hline United Kingdom & 832,000 & 495,000 & $59 \%$ & 2.48 & 7.92 \\
\hline China & 968,000 & 729,000 & $75 \%$ & 3.64 & 9.64 \\
\hline United States (48) & $2,704,000$ & 540,000 & $20 \%$ & 2.70 & 6.96 \\
\hline Indonesia & $6,622,000$ & $2,097,000$ & $32 \%$ & 10.49 & 12.99 \\
\hline Chile & $3,185,000$ & 152,000 & $5 \%$ & 0.76 & 2.21 \\
\hline Mexico & $3,634,000$ & 511,000 & $14 \%$ & 2.56 & 4.65 \\
\hline South Africa & $1,184,000$ & 237,000 & $20 \%$ & 1.19 & 3.23 \\
\hline Global & $154,082,000$ & $25,298,000$ & $16 \%$ & 126 & 315 \\
\hline
\end{tabular}

${ }^{a}$ EEZ total and available area is estimated based on $2 \mathrm{~km}$ equal area grid projections. Values have been rounded to the nearest thousands.

Figure 14 and Figure 15 show the generation potential for terrestrial and offshore wind sites by resource classification and distance-to-grid/water depth for selected countries/EEZs. In these figures, the resource has been cut off at $26 \% \mathrm{nCF}$ to focus on the resource that is more likely to be economically competitive. ${ }^{25}$ In general, offshore areas have a larger quantity of high-quality than land areas. Figure 14 shows that a significant quantity of terrestrial resource resides in the $26-30 \% \mathrm{nCF}$ range.

${ }^{25}$ Prior to this point, tables showing generation potential include all resource classifications, classes 1- 9. 


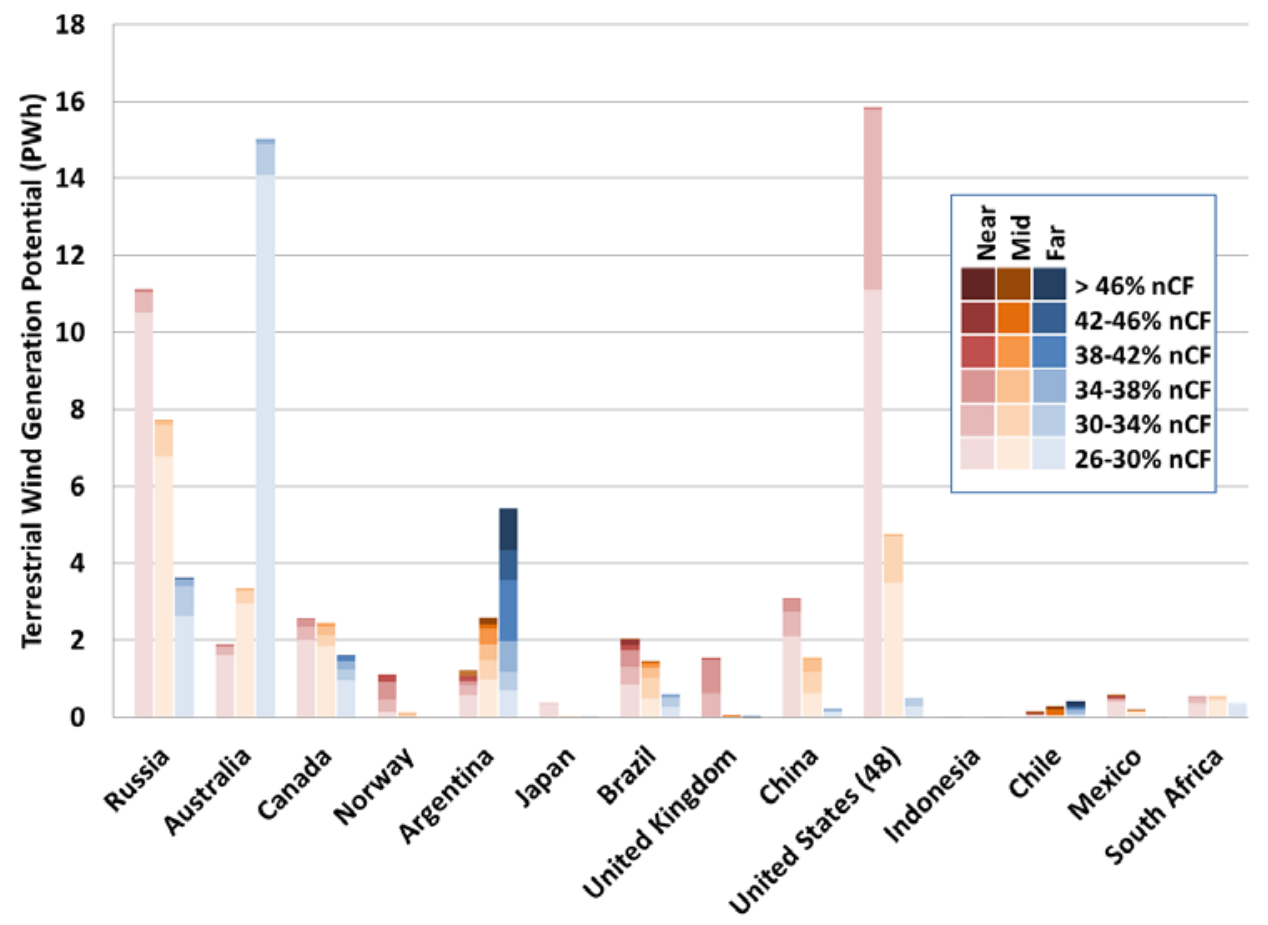

Figure 14. Terrestrial wind potential for net capacity factors above $26 \%$ for selected countries, binned by distance to grid ('near', 'mid', 'far') and resource quality (as defined by net capacity factor).

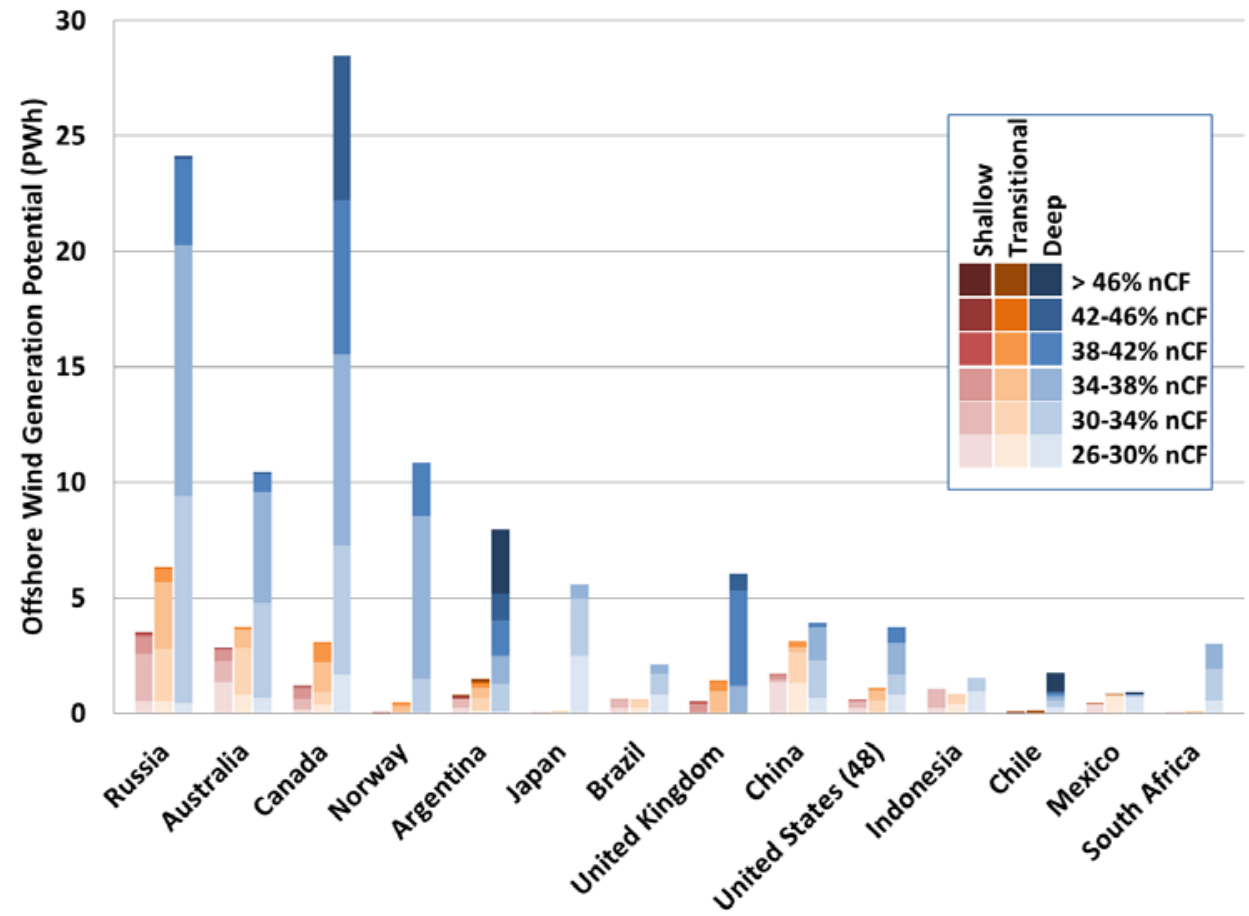

Figure 15. Offshore wind potential for net capacity factors above $26 \%$ for selected EEZs, binned by water depth ('shallow', 'transitional', 'deep) and resource quality (as defined by net capacity factor). 


\section{Discussion of Uncertainty}

In this analysis, there are multiple areas of uncertainty as a result of our computational methods and parametric assumptions; we briefly discuss these sources of uncertainties in this section.

We attributed computational uncertainty to the construction of the wind speed distributions, the estimation of air density, the adjustment of a power curve for altitude, and the design of a synthetic transmission network. Of these, the estimation of wind speed distributions is likely the most significant source of computational uncertainty, which we quantify using a normalized root mean square deviation in Section 2.2.

We attribute parametric uncertainty to the representative wind turbine characteristics (hub height; availability; array spacing; array efficiency; deployment density), protected area classification, land use suitability factors, elevation and slope cutoffs, sea ice criteria, minimum and maximum distances to shore, and water depth limits. Of these, the assumed turbine characteristics (especially the array spacing and array efficiency) and land use suitability factors are likely the most significant sources of parametric uncertainties; although, we have not quantified them here. For the future, we would conduct a parametric analysis in order to provide a qualitative assessment of these data-driven uncertainties.

We summarize some areas of improvement for our methods to better refine our estimations of global wind technical potential and to help mitigate uncertainty:

- Define wind speed distributions directly from the mesoscale modeling outputs rather than estimating them from summary statistics.

- Improve the interpolation between hub heights using a wind profile power law by processing the wind speeds at various heights to develop a function to describe the relationship between heights.

- Include IEC class III turbines for low-speed sites as well as allow for dynamic turbine selection based on the wind regime and IEC61400-1 (2005) design parameters.

- Use alternative deployment densities based on recent literature to better account for wind speed depression effects of large-scale wind deployment.

- Quantify the land use exclusions by land use categories for each country to assess the validity the assumed suitability factors.

- Capture coastline permafrost exclusions for offshore wind.

- Include a shore-to-grid accessibility distance in order to have and more complete accessibility metric for offshore wind. 


\section{Comparison with Other Global Analyses}

To broadly validate our methods, we compare the NREL estimates of global wind technical potential presented in this paper with other global wind resource estimates from Hoogwijk et al. (2004), Arent et al. (2012), and Lu et al. (2009). These studies use similar data layers for exclusions whereby providing comparable estimates to NREL for total available area, i.e., total area minus geographic exclusions (although, some differences exist due to cold climate assumptions). The overall technical potential can vary from study to study due to differences in methods and assumptions, e.g., turbine deployment density, representative wind turbine power curve, turbine availability, array efficiency, wind speed conversion method to hub height, power correction for altitude, etc. Table 9 summarizes the methods and assumptions used in each study.

Table 9. Summary of methods and assumptions between the current NREL analysis and other related studies.

\begin{tabular}{|c|c|c|c|c|}
\hline Parameter & NREL & Hoogwijk et al. (2004) & $\begin{array}{l}\text { Arent et al. } \\
(2012)\end{array}$ & Lu et al. (2009) \\
\hline Wind regime & Terrestrial and offshore & Terrestrial & Offshore & Terrestrial and offshore \\
\hline $\begin{array}{l}\text { Wind data } \\
\text { source }\end{array}$ & $\begin{array}{l}\text { NCAR's Climate Four } \\
\text { Dimensional Data } \\
\text { Assimilation }\end{array}$ & $\begin{array}{l}\text { Climate Research Unit } \\
\text { database }\end{array}$ & $\begin{array}{l}\text { NOAA's } \\
\text { Blended Sea } \\
\text { Winds }^{\text {a }}\end{array}$ & $\begin{array}{l}\text { Goddard Earth } \\
\text { Observing System Data } \\
\text { Assimilation System } \\
\text { (GEOS-5 DAS) }\end{array}$ \\
\hline $\begin{array}{l}\text { Wind data } \\
\text { spatial } \\
\text { resolution }\end{array}$ & $\begin{array}{l}0.4^{\circ}(\sim 40 \mathrm{~km}) \\
\text { Mollweide equal-area } \\
\text { projection }\end{array}$ & $0.5^{\circ} \times 0.5^{\circ}$ & $0.25^{\circ} \times 0.25^{\circ}$ & $\begin{array}{l}2 / 3^{\circ} \text { longitude } \times 1 / 2^{\circ} \\
\text { latitude } \\
(\sim 66.7 \times 50 \mathrm{~km} \text { at mid- } \\
\text { latitudes })\end{array}$ \\
\hline $\begin{array}{l}\text { Wind data } \\
\text { temporal } \\
\text { resolution }\end{array}$ & $\begin{array}{l}288 \text { month-hour } \\
\text { averages from 1985- } \\
2005\end{array}$ & $\begin{array}{l}\text { Monthly average wind } \\
\text { speeds aggregated to } \\
\text { annual averages; data } \\
\text { from 1961-1990 }\end{array}$ & $\begin{array}{l}\text { Monthly average } \\
\text { wind speeds } \\
\text { aggregated to } \\
\text { annual averages; } \\
\text { data from } 1987 \text { - } \\
2006\end{array}$ & $\begin{array}{l}\text { Wind speed data from } \\
2004-2009\end{array}$ \\
\hline $\begin{array}{l}\text { Reference } \\
\text { height }\end{array}$ & Multiple layers & $10 \mathrm{~m} \mathrm{AGL}$ & $10 \mathrm{~m} \mathrm{AGL}$ & Multiple layers \\
\hline Hub height & 90m AGL & Function of rated power & $90 \mathrm{~m}$ AGL & $100 \mathrm{~m}$ AGL \\
\hline $\begin{array}{l}\text { Scaling to } \\
\text { hub height }\end{array}$ & $\begin{array}{l}\text { Interpolate between } \\
58.1 \text { and } 115.1 \mathrm{~m} \mathrm{AGL}\end{array}$ & $\begin{array}{l}\text { Logarithmic wind speed } \\
\text { profile }\end{array}$ & $\begin{array}{l}\text { Wind profile } \\
\text { power law; sheer } \\
\text { exponent of } 0.11\end{array}$ & $\begin{array}{l}\text { Apply a cubic spline fit } \\
\text { to data at } 71,201 \text { and } \\
332 \mathrm{~m} \text { AGL }\end{array}$ \\
\hline $\begin{array}{l}\text { Minimum } \\
\text { quality }\end{array}$ & No cutoff ${ }^{b}$ & $4 \mathrm{~m} / \mathrm{s}$ at $10 \mathrm{~m} \mathrm{AGL}$ & $\begin{array}{l}\text { (a) } 20 \% \mathrm{nCF} ;(\text { b) } \\
8 \mathrm{~m} / \mathrm{s} \text { at } 90 \mathrm{~m} \\
\text { AGL }\end{array}$ & $\begin{array}{l}\text { (a) } 20 \% \mathrm{nCF} \text {; (b) no } \\
\text { cutoff }\end{array}$ \\
\hline $\begin{array}{l}\text { Turbine } \\
\text { availability }\end{array}$ & 0.95 & 0.95 & 0.95 & 1.0 \\
\hline $\begin{array}{l}\text { Array } \\
\text { efficiency }\end{array}$ & 0.90 & 0.90 & 0.90 & 1.0 \\
\hline $\begin{array}{l}\text { Turbine } \\
\text { deployment } \\
\text { density }\end{array}$ & $5 \mathrm{MW} / \mathrm{km}^{2}$ & $4 \mathrm{MW} / \mathrm{km}^{2}$ & $5 \mathrm{MW} / \mathrm{km}^{2}$ & $\begin{array}{l}\text { Terrestrial: } 9 \mathrm{MW} / \mathrm{km}^{2} \\
\text { Offshore: } 5.84 \mathrm{MW} / \mathrm{km}^{2}\end{array}$ \\
\hline $\begin{array}{l}\text { Power curve } \\
\text { correction for } \\
\text { altitude }\end{array}$ & $\begin{array}{l}\text { Apply a correction } \\
\text { factor as a function of } \\
\text { air density. }\end{array}$ & No correction applied. & $\begin{array}{l}\text { No correction } \\
\text { needed for } \\
\text { offshore. }\end{array}$ & $\begin{array}{l}\text { Apply a correction factor } \\
\text { as a function of pressure } \\
\text { and temperature. }\end{array}$ \\
\hline $\begin{array}{l}\text { Power output } \\
\text { estimates }\end{array}$ & $\begin{array}{l}\text { Construct wind speed } \\
\text { distributions based on }\end{array}$ & $\begin{array}{l}\text { Use linear equation of } \\
\text { full load hours as a }\end{array}$ & $\begin{array}{l}\text { Construct } \\
\text { Weibull wind }\end{array}$ & $\begin{array}{l}\text { Calculate the power } \\
\text { output from } 2.5 \mathrm{MW} \text { and }\end{array}$ \\
\hline
\end{tabular}




\begin{tabular}{|c|c|c|c|c|}
\hline Parameter & NREL & Hoogwijk et al. (2004) & $\begin{array}{l}\text { Arent et al. } \\
(2012)\end{array}$ & Lu et al. (2009) \\
\hline & $\begin{array}{l}\text { mesoscale model wind } \\
\text { statistics and convolve } \\
\text { with power curves for a } \\
\text { composite } 3.5 \mathrm{MW} \\
\text { turbines. }\end{array}$ & $\begin{array}{l}\text { function of the wind } \\
\text { speed; function accounts } \\
\text { for the characteristics of } \\
\text { the Weibull distribution } \\
\text { and six commercial wind } \\
\text { turbines. }\end{array}$ & $\begin{array}{l}\text { speed } \\
\text { distributions and } \\
\text { convolve with a } \\
\text { power curve for } \\
\text { a composite } 3.5 \\
\text { MW turbine }\end{array}$ & $\begin{array}{l}\text { 3.6 MW GE turbines for } \\
\text { terrestrial and offshore, } \\
\text { respectively. }\end{array}$ \\
\hline $\begin{array}{l}\text { Exclusion } \\
\text { layers }\end{array}$ & $\begin{array}{l}\text { Terrestrial: altitude; } \\
\text { slope; protected areas; } \\
\text { permanent snow, ice, } \\
\text { water; urban areas; } \\
\text { land use suitability. } \\
\text { Offshore: distance to } \\
\text { shore; protected areas; } \\
\text { water depth; sea ice. }\end{array}$ & $\begin{array}{l}\text { Terrestrial: wind regime; } \\
\text { altitude; protected areas; } \\
\text { urban areas; land use } \\
\text { suitability. }\end{array}$ & $\begin{array}{l}\text { Offshore: wind } \\
\text { regime; } \\
\text { protected areas; } \\
\text { distance to shore; } \\
\text { water depth. }\end{array}$ & $\begin{array}{l}\text { Terrestrial: wind regime; } \\
\text { slope; permanent snow, } \\
\text { ice, water; developed and } \\
\text { urban areas; forests. } \\
\text { Offshore: wind regime; } \\
\text { distance to shore; water } \\
\text { depth. }\end{array}$ \\
\hline
\end{tabular}

${ }^{a}$ Blended Sea Winds is a combination of the National Centers for Environmental Prediction Reanalysis dataset and the European Center for Medium-Range Weather Forecasts data assimilation products.

${ }^{a}$ We do not exclude low-quality wind resource in this study, but instead reserve this decision making to modelers/models using these global wind supply curves.

First, we compare our (NREL) estimates with global terrestrial resource estimates from Hoogwijk et al. (2004). To sync up with Hoogwijk's minimum wind speed assumption of $4 \mathrm{~m} / \mathrm{s}$ at $10 \mathrm{~m}$ AGL, we exclude resource below 26\% nCF (classes 1-3). Below this threshold, we lose $73 \%$ of global area which is approximately consistent with the $80 \%$ excluded in Hoogwijk due to wind regime. ${ }^{26}$ Figure 16 shows that the total land area before exclusions is consistent between our study and Hoogwijk, but available area differs. We attribute these differences to lower quality wind resource (based on net capacity factor) and the lack of cold zone exclusions (permafrost/snow/ice) in Hoogwijk. In Canada, both estimates exclude about $50 \%$ of land area due to wind regime, but the Hoogwijk study does not remove cold zones and therefore retains more available area. In Russia, we lose only $26 \%$ of area due to wind regime, but the Hoogwijk study loses about $75 \%$ of area. However, the cold zone exclusions used for our estimates eliminate another $60 \%$ of the remaining area in Russia, making the net available land on par with Hoogwijk. In Africa, we lose $86 \%$ of land area due to wind regime, but the Hoogwijk study loses about $95 \%$. Although we have less available land area in regions such as the United States, Russia, and Oceania compared to Hoogwijk, we estimate higher generation potential in these regions (Figure 17), highlighting the lower quality wind resource in Hoogwijk compared to NREL. Global resource for NREL (above the 26\% nCF threshold) totals 168 PWh compared to Hoogwijk's 96 PWh.

\footnotetext{
${ }^{26}$ Excluding the class 4 resource $(26-30 \% \mathrm{nCF})$ from our study expands the global land area exclusion to $89 \%$.
} 

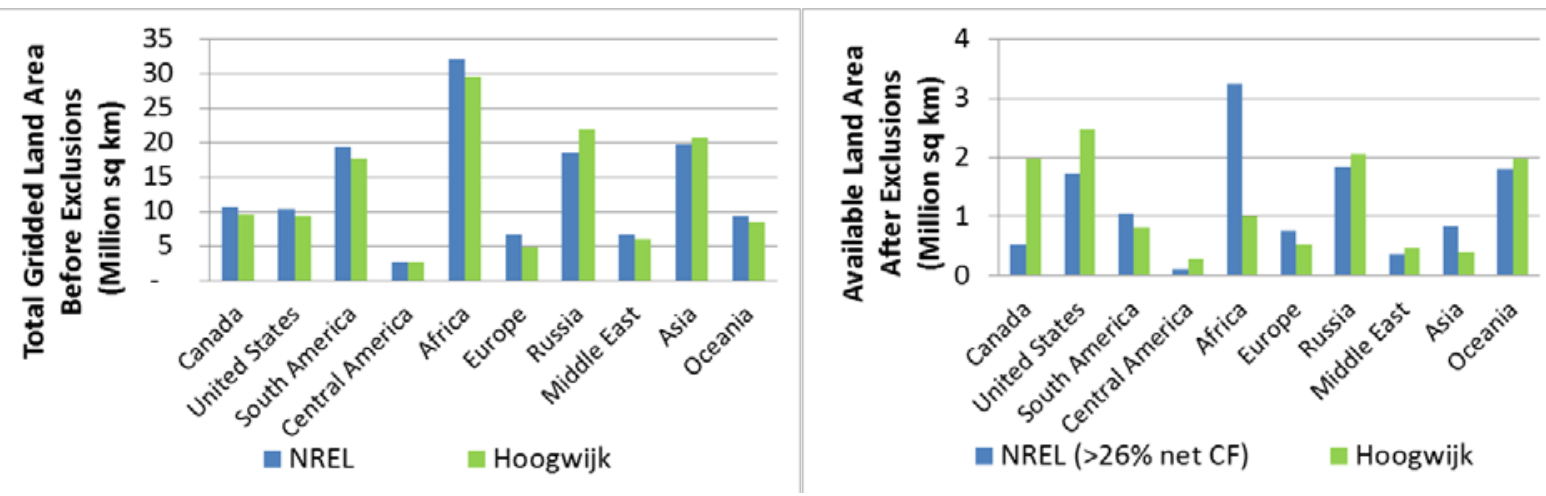

Figure 16. Comparison with Hoogwijk et al. (2004): total land area and usable area with minimum resource quality cutoffs.

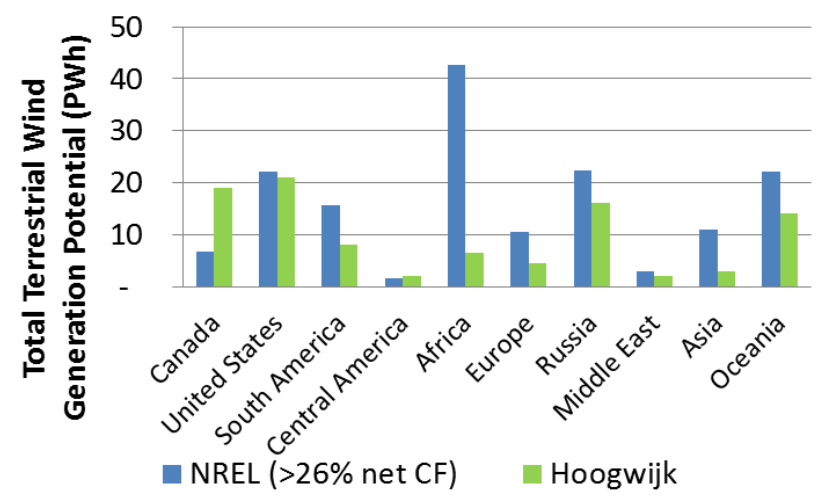

Figure 17. Comparison with Hoogwijk et al. (2004): total generation potential for terrestrial wind with minimum resource quality cutoffs.

Next, we compare our (NREL) estimates with the offshore resource estimates from Arent et al. (2012). To harmonize with Arent's minimum wind speed of $8 \mathrm{~m} / \mathrm{s}$ at $90 \mathrm{~m}$ AGL, we exclude resource below $34 \% \mathrm{nCF}$ (classes 1-5). This threshold is based on an estimated $35 \% \mathrm{nCF}$ that results from convolving a $3.5 \mathrm{MW}$ IEC class I power curve with a Weibull function with mean= 8 and shape parameter $=2$. Above this threshold, our offshore resource estimates contain less high quality resource (based on net capacity factor) than in the Arent study as seen in Figure 18 for selected countries. Given that most of the technical assumptions are aligned between these two studies, the difference in offshore resource quality is likely driven by differences in the underlying wind datasets; although, varying technical potential for countries such as Canada and Russia are also driven by sea ice exclusions used in our analysis alone. 


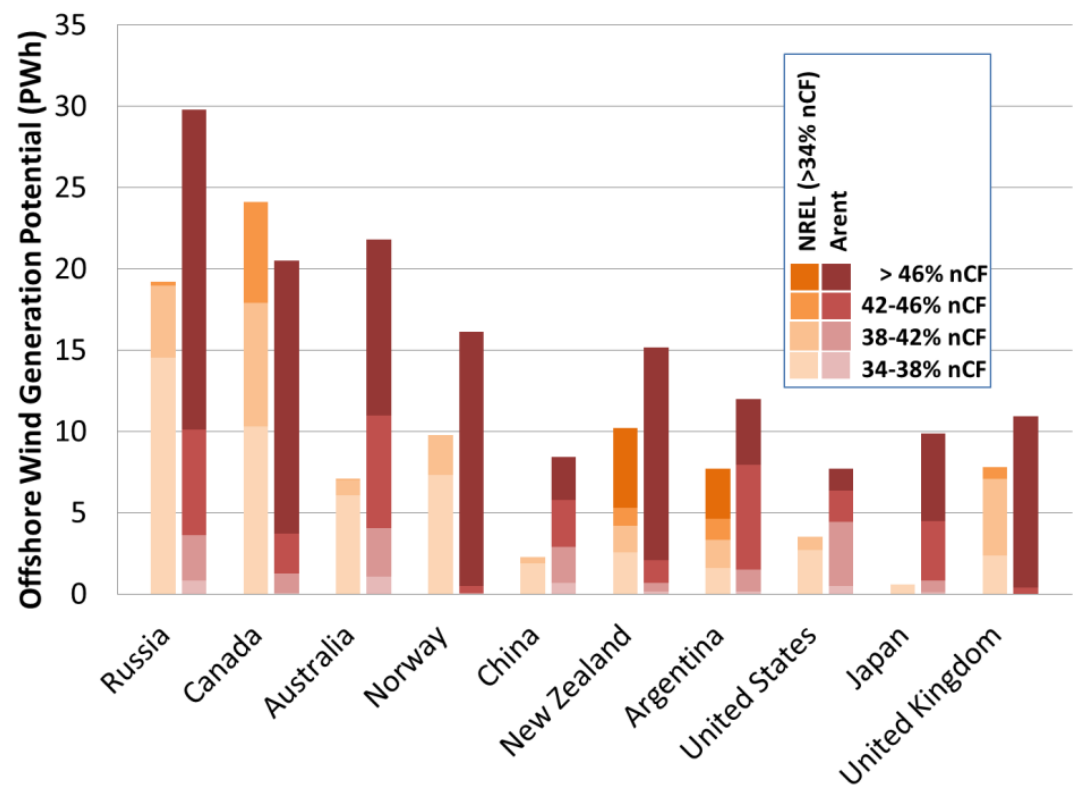

Figure 18. Comparison with Arent et al. (2012): generation potential by resource quality for selected countries.

To explore the differences in the underlying wind datasets used for our current NREL estimates and Arent, we compare the CFDDA-based annual average wind speeds at 58 and $115 \mathrm{~m} \mathrm{AGL}$ from the ten sample CFDDA sites shown in Figure 5 (see Section 2.3) against the distributions of annual average wind speeds from the Blended Sea Winds dataset at 90m AGL in the same spatial areas. Figure 19 shows that the CFDDA annual average speeds are generally within or below the second quartile ranges of the Blended Sea Wind annual average data. This observation suggests that the offshore wind speeds used in our estimates are generally lower than those used by Arent. In total, the global offshore wind resource of $302 \mathrm{PWh}$ in the Arent study exceeds the $148 \mathrm{PWh}$ estimate in this current NREL study (above 34\% nCF). 


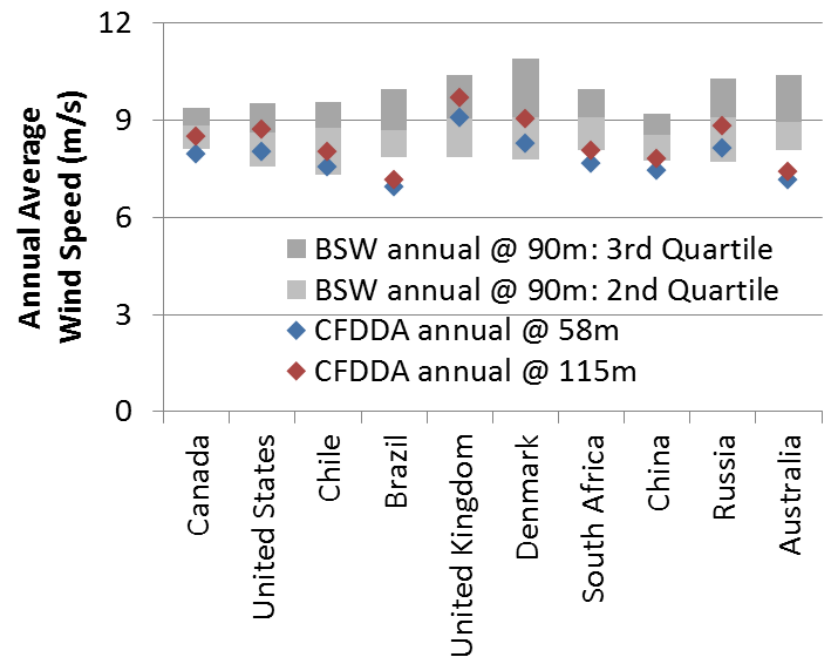

Figure 19. Comparison of CFDDA-derived annual average wind speeds with the second and third quartiles of Blended Sea Winds (BSW) at ten specific CFDDA offshore locations.

Finally, we compare both the terrestrial and offshore wind potential in our (NREL) study with Lu et al. (2009) who report resource potential based on a $20 \%$ nCF cutoff and no cutoff. To better align with $\mathrm{Lu}$, we adjust our results to include resource in protected areas and we use a deployment density of 9 and $5.42 \mathrm{MW} / \mathrm{km}^{2}$ for terrestrial and offshore wind. The significantly higher terrestrial deployment density in the Lu study is based on tighter turbine spacing (greater than seven by four rotor diameters) and a smaller $(2.5 \mathrm{MW})$ turbine size than we assume for our study. ${ }^{27}$ The slightly higher offshore deployment density in the Lu study is based on the same ten by five rotor diameter spacing assumed in our study, but with and a slightly larger (3.6 MW) turbine size.

Figure 20 shows terrestrial wind generation potential by resource quality cutoff for the entire globe and for the lower 48 United States. The global terrestrial resource with no minimum cutoff is generally well aligned, but the Lu study loses a greater percentage of resource at the $20 \%$ cutoff. From this observation, we surmise that the Lu study excludes less land area that our study, but we estimate more high-quality wind resource (with respect to net capacity factor).

We make a similar presumption in comparing resource for the lower 48 United States: the Lu study has higher generation potential with no resource cutoff due to retaining more land area; although, both studies have similar estimates after the $20 \%$ cutoff, indicating differences in resource quality.

${ }^{27}$ For this comparison, we assume that the net capacity factors calculated using a $3.5 \mathrm{MW}$ composite turbine are a sufficient approximation for the net capacity factors for a $2.5 \mathrm{MW}$ turbine. 

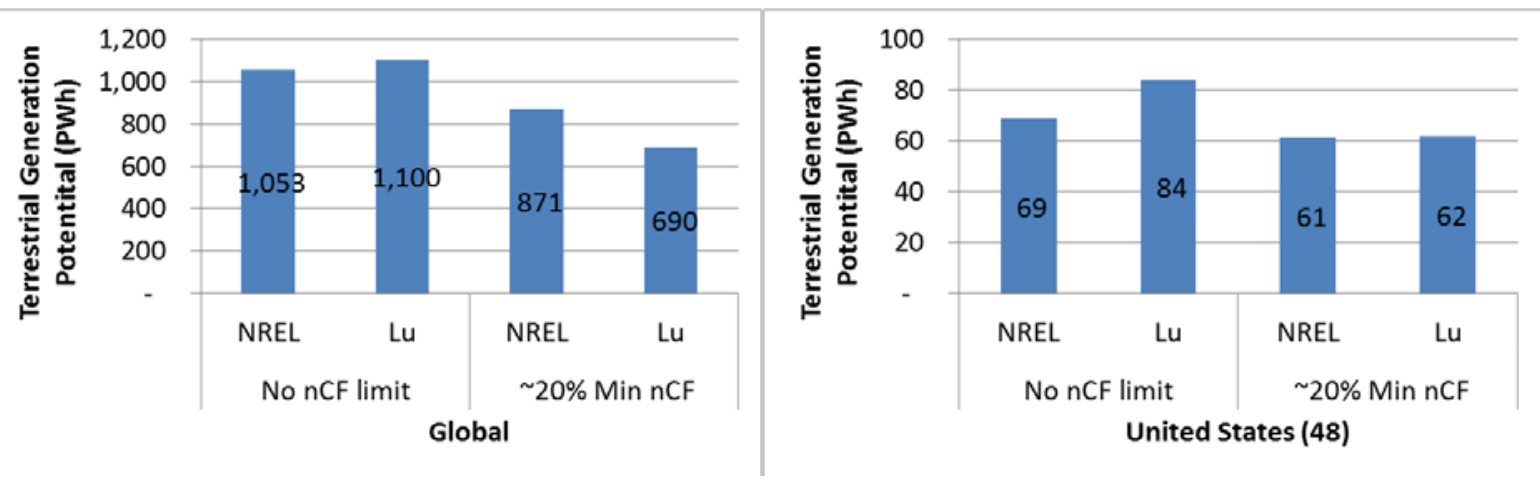

Figure 20. Comparison with Lu et al. (2009): terrestrial wind generation potential by resourcequality cutoff between for the entire global and the lower 48 United States.

Figure 21 shows offshore wind generation potential within 50 nautical miles by depth class and resource quality cutoff for the entire global and the lower 48 United States. The depth classifications are generally aligned for 'shallow' and 'transitional', but Lu limits the depth to 200 meters compared to the 1,000 meters in our study. As such, the estimates for shallow and transitional waters are generally well aligned between the studies, but the estimates for deep water are lower in the Lu study. As with the terrestrial wind comparison, the Lu study loses a greater percentage of resource when applying the $20 \%$ cutoff due to differences in resource quality.
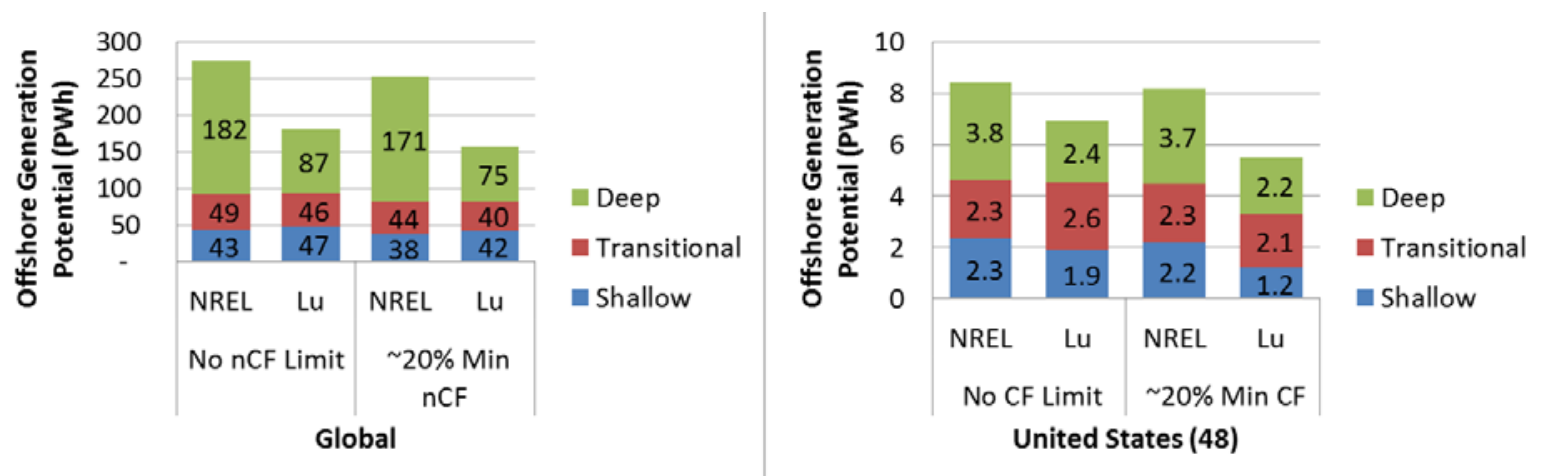

Figure 21. Comparison with Lu et al. (2009): offshore wind generation potential within 50 nautical miles by depth class and resource quality cutoff for the entire global and the lower 48 United States. 


\section{Summary}

In this paper, we present the methodologies and assumptions used in developing robust estimates of global terrestrial and offshore wind technical potential. We begin with NCAR's CFDDA mesoscale reanalysis climate dataset. From gridded wind speed statistics, we create wind speed distributions and convolve them with a representative power curves to estimate energy output for a wind farm at each location. Then we apply geospatial filters to exclude areas deemed unlikely to be developed, and classify remaining area by resource quality and accessibility.

Terrestrial wind technical potential is aggregated according to wind quality (as classified by net capacity factor), distance-to-grid, and country. Exclusions are based on elevation, slope, protected areas, permanent ice/snow/water, environmental protected areas, and land use suitability. Offshore wind resource potential is aggregated according to wind quality, water depth, and Exclusive Economic Zones. Exclusions are based on minimum and maximum distance to shore, marine protected areas, maximum marine depth, and months of sea ice.

We estimate the total global wind generation potential of $560 \mathrm{PWh}$ for terrestrial wind with $90 \%$ of resource classified as low-to-mid quality, and $315 \mathrm{PWh}$ for offshore wind with $67 \%$ classified as mid-to-high quality. These estimates are based on 3.5 MW IEC composite wind turbines with $90 \mathrm{~m}$ hub heights, $95 \%$ availability, $90 \%$ array efficiency, and $5 \mathrm{MW} / \mathrm{km}^{2}$ deployment density in non-excluded areas.

We compare our estimates to similar global studies. We examine the underlying differences in methods and technical assumptions for each study and compare resource estimates using generally harmonized assumptions.

The global wind supply curves discussed in this paper contribute to the improvement of the representation of renewable energy technologies integrate assessment models. This work is important for accurately capturing the potential contribution of renewable energy technologies to the global electric power sector.

\section{Acknowledgements}

The research leading to these results has received funding from the U.S. Department of Energy Office of International Climate and Technology as well as the European Union's Seventh Programme FP7/2007-2013 under grant agreement $N^{\circ} 308329$ (ADVANCE). We thank the National Center for Atmospheric Research for providing the underlying dataset for this work. We thank Yvonne Scholz (German Aerospace Center - DRL), Mary Lukkonen (NREL), Dan Steinberg (NREL), and Doug Arent (NREL) for their review of this paper. 


\section{References}

Adams, A. S., Keith, D. W. (2013). Are global wind power resource estimates overstated? Environmental Research Letters, 8(1), p. 1-9.

Arent, D., Sullivan, P., Heimiller, D., Lopez, A., Eurek, K., Badger, J., Jorgensen, H.E., Kelly, M., Clarke, L., Luckow, P. (2012). Improved offshore wind resource assessment in global climate stabilization scenarios. NREL/TP-6A20-55049. Golden, CO: National Renewable Energy Laboratory.

Battisti, L., Fedrizzi, R., Brighenti, A., Laakso, T. (April 2006). Sea ice and icing risk for offshore wind turbines. In Proceedings of the OWEMES, pp. 20-22.

Bontemps, S., Defourny, P., Van Bogaert, E. (2009). GLOBCOVER 2009 products description and validation report. European Space Agency.

Deng, Y.Y., Haigh, M., Pouwels, W., Ramaekers, L., Brandsma, R., Schimschar, S., Grözinger, J. and de Jager, D. (2015). Quantifying a realistic, worldwide wind and solar electricity supply. Global Environmental Change,31, pp.239-252.

Denholm, P., Hand, M., Jackson, M. and Ong, S. (2009). Land-use requirements of modern wind power plants in the United States. NREL/TP-6A2-45834. Golden, CO: National Renewable Energy Laboratory.

Dilley, L. M., Hulse, L. (2007). Foundation design of wind turbines in Southwestern Alaska, a case study. The Arctic Energy Summit 2007-2008, Anchorage, Alaska.

Elliott, D. L., Holladay, C. G., Barchet, W. R., Foote, H. P., Sandusky, W. F. (1987). Wind energy resource atlas of the United States. NASA STI/Recon Technical Report N, 87.

Grell, G. A., Dudhia, J., Stauffer, D. R. (1995): A description of the fifth-generation Penn State/NCAR mesoscale model (MM5). Tech. Rep. NCAR/TN-398, NCAR Tech. Note, 122 pp. Available from UCAR Communications, P. O. Box 3000, Boulder, CO, 80307.

Gruber, S. (2012). Derivation and analysis of a high-resolution estimate of global permafrost zonation. The Cryosphere, 6, pp. 221-233. doi:10.5194/tc-6-221-2012.

Hoogwijk, M., de Vries, B., Turkenburg, W. (2004). Assessment of the global and regional, geographic, technical and economic potential of onshore wind energy. Energy Economics, 26, pp. 889-919.

Intergovernmental Panel on Climate Change (IPCC). (2011). Special report renewable energy sources and climate change mitigation. In: Edenhofer O, Pichs-Madruga R, Sokona Y, Seyboth K, Matschoss P, Kadner S, Zwickel T, Eickemeier P, Hansen G, Schlömer S, Stechow CV (eds), Intergovernmental Panel on Climate Change.

IPCC. (2014). Fifth Assessment Report (AR5). https://www.ipcc.ch/report/ar5/. Accessed August 30, 2016. 
International Electrotechnical Comission (IEC) 61400-1 (2005). Wind Turbines - Part 1: Design Requirements. International Technical Commission, Geneva.

IEC 61400-12-1 (2005). Wind Turbines - Part 12-1: Power performance measurements of electricity producing wind turbines. International Technical Commission, Geneva.

International Energy Agency (IEA) Wind. (October 2009). IEA Wind Task 19 expert group study on recommendations for wind energy projects in cold climates. International Energy Agency.

International Union for the Conservation of Nature (IUCN) and United Nations Environment Programme (UNEP). (2010). The world database on protected areas (WDPA). Cambridge, UK: UNEP-WCMC. www.protectedplanet.net.

Lantuit, H., Overduin, P., Couture, N., Wetterich, S., Aré, F., Atkinson, D., Brown, J., Cherkashov, G., Drozdov, D., Forbes, D.L. and Graves-Gaylord, A. (2012). The Arctic coastal dynamics database: a new classification scheme and statistics on Arctic permafrost coastlines. Estuaries and Coasts, 35(2), pp.383-400.

Leemis, L.M. and McQueston, J.T. (2008). Univariate distribution relationships. The American Statistician, 62(1), pp.45-53.

Lopez, A., Roberts, B., Heimiller, D., Blair, N., Porro, G. (2012). US renewable energy technical potentials: a GIS-based analysis. Contract, 303, pp. 275-3000.

Lu, X., McElroy, M. B., Kiviluoma, J. (2009). Global potential for wind-generated electricity. Proc. Natl. Acad. Sci.

Meridian Energy Ltd. (2010). Meridian Energy annual report: for year ended 30 June 2010.

Miller, L. M., Brunsell, N. A., Mechem, D. B., Gans, F., Monaghan, A. J., Vautard, R., Keith, D.W., Kleidon, A. (2015). Two methods for estimating limits to large-scale wind power generation. Proceedings of the National Academy of Sciences, 112(36), pp. 11169-11174.

Musial, W., Ram, B. (2010). Large-scale offshore wind power in the United States: assessment of opportunities and barriers. NREL/TP-500-40745. Golden, CO: National Renewable Energy Laboratory.

Musial, W., Butterfield, C. (2004). Future for offshore wind energy in the United States. NREL/CP-500-36313. In Energy Ocean 2004 Conference, 16 pp. Palm Beach, FL.

National Center for Atmospheric Research (NCAR). (2011). CFDDA global $40 \mathrm{~km}$ reanalysis.

Parkinson, C. L., Cavalieri, D. J., Gloersen, P., Zwally, H. J., Comiso, J. C. (1999). Arctic sea ice extents, areas, and trends, 1978-1996. Journal of Geophysical Research: Oceans (19782012), 104(C9), pp. 20837-20856. 
Seguro, J.V. and Lambert, T.W. (2000). Modern estimation of the parameters of the Weibull wind speed distribution for wind energy analysis. Journal of Wind Engineering and Industrial Aerodynamics, 85(1), pp.75-84.

Svenningsen, L. (April 2010). Proposal of an improved power curve correction. European Wind Energy Conference \& Exhibition 2010, Warsaw, Poland.

U.S. Department of Energy (US DOE). (2015). Wind Vision: A New Era for Wind Power in the United States. DOE/GO-102015-4557. U.S. Department of Energy, Washington, DC. 


\section{Appendix}

Table A.1. Summary of terrestrial wind supply curve model parameters.

\begin{tabular}{lcc}
\hline Parameter & Value & Units \\
\cline { 2 - 3 } Turbine Deployment Density & 5 & $\mathrm{MW} / \mathrm{km}^{2}$ \\
Wind Turbine Array Efficiency & 0.9 & - \\
Turbine Availability & 0.95 & - \\
Class 2 Minimum Capacity Factor & 0.18 & - \\
Capacity Factor Bin Step Size & 0.04 & - \\
Near Distance Upper Limit & 50 & miles \\
Transitional Distance Upper Limit & 100 & miles \\
Far Distance Upper Limit & 5000 & miles \\
Elevation Maximum & 2500 & meters \\
Slope Maximum & 20 & degrees \\
\hline
\end{tabular}

Table A.2. Summary of offshore wind supply curve model parameters.

\begin{tabular}{lcc}
\hline Parameter & Value & Units \\
\cline { 2 - 3 } Turbine Deployment Density & 5 & $\mathrm{MW} / \mathrm{km}^{2}$ \\
Wind Turbine Array Efficiency & 0.9 & - \\
Turbine Availability & 0.95 & - \\
Class 2 Minimum Capacity Factor & 0.18 & - \\
Capacity Factor Bin Step Size & 0.04 & - \\
Minimum Distance to Shore & 5 & nautical miles \\
Distance to Shore Near Max & 20 & nautical miles \\
Distance to Shore Intermediate Max & 50 & nautical miles \\
Maximum Distance to Shore & 100 & nautical miles \\
Shallow Depth Upper Limit & 30 & meters \\
Transitional Depth Upper Limit & 60 & meters \\
Deep Depth Upper Limit & 1000 & meters \\
Maximum Months of Sea Ice Allowed & 8 & months \\
\hline
\end{tabular}

Table A.3. Percentages of land area excluded for selected countries.

\begin{tabular}{lrrrrr}
\hline \multirow{2}{*}{$\begin{array}{l}\text { Country } \\
\text { Russia }\end{array}$} & Elevation; Slope & $\begin{array}{r}\text { Protected } \\
\text { Areas }\end{array}$ & Water $^{\text {a }}$ & $\begin{array}{r}\text { Land Use } \\
\text { Suitability }\end{array}$ & Available Area \\
\cline { 2 - 6 } Australia & $0 \%$ & $1 \%$ & $67 \%$ & $18 \%$ & $14 \%$ \\
Canada & $0 \%$ & $0 \%$ & $1 \%$ & $29 \%$ & $70 \%$ \\
Norway & $1 \%$ & $8 \%$ & $61 \%$ & $22 \%$ & $9 \%$ \\
Argentina & $1 \%$ & $17 \%$ & $23 \%$ & $31 \%$ & $28 \%$ \\
Japan & $8 \%$ & $0 \%$ & $3 \%$ & $38 \%$ & $51 \%$ \\
Brazil & $0 \%$ & $14 \%$ & $1 \%$ & $59 \%$ & $26 \%$ \\
United Kingdom & $0 \%$ & $9 \%$ & $4 \%$ & $56 \%$ & $31 \%$ \\
China & $0 \%$ & $27 \%$ & $5 \%$ & $24 \%$ & $45 \%$ \\
United States & $29 \%$ & $3 \%$ & $8 \%$ & $21 \%$ & $38 \%$ \\
Indonesia & $3 \%$ & $6 \%$ & $4 \%$ & $49 \%$ & $39 \%$ \\
Chile & $1 \%$ & $8 \%$ & $7 \%$ & $51 \%$ & $33 \%$ \\
Mexico & $22 \%$ & $13 \%$ & $4 \%$ & $27 \%$ & $34 \%$ \\
South Africa & $3 \%$ & $0 \%$ & $1 \%$ & $53 \%$ & $43 \%$ \\
\hline${ }^{2}$ Water bo & $3 \%$ & $1 \%$ & $32 \%$ & $64 \%$ \\
\hline
\end{tabular}

${ }^{\mathrm{a}}$ Water bodies; snow; ice; permafrost 
Table A.4. Percentages of offshore area excluded for selected EEZs.

\begin{tabular}{lrrrrr}
\hline \multirow{2}{*}{ EEZ } & $\begin{array}{r}\text { Distance to } \\
\text { Shore }\end{array}$ & $\begin{array}{r}\text { Protected } \\
\text { Areas }\end{array}$ & $\begin{array}{r}\text { Water } \\
\text { Depth }\end{array}$ & Sea Ice & Available Area \\
\cline { 2 - 6 } Russia & 0.36 & $1 \%$ & $13 \%$ & $21 \%$ & $28 \%$ \\
Australia & 0.45 & $6 \%$ & $23 \%$ & $0 \%$ & $26 \%$ \\
Canada & 0.41 & $0 \%$ & $8 \%$ & $17 \%$ & $34 \%$ \\
Norway & 0.47 & $0 \%$ & $12 \%$ & $5 \%$ & $37 \%$ \\
Argentina & 0.44 & $0 \%$ & $5 \%$ & $0 \%$ & $51 \%$ \\
Japan & 0.52 & $0 \%$ & $37 \%$ & $0 \%$ & $11 \%$ \\
Brazil & 0.58 & $4 \%$ & $18 \%$ & $0 \%$ & $19 \%$ \\
United Kingdom & 0.32 & $0 \%$ & $9 \%$ & $0 \%$ & $60 \%$ \\
China & 0.23 & $0 \%$ & $1 \%$ & $0 \%$ & $75 \%$ \\
United States 448$)$ & 0.47 & $15 \%$ & $18 \%$ & $0 \%$ & $20 \%$ \\
Indonesia & 0.27 & $0 \%$ & $41 \%$ & $0 \%$ & $32 \%$ \\
Chile & 0.59 & $1 \%$ & $36 \%$ & $0 \%$ & $5 \%$ \\
Mexico & 0.43 & $1 \%$ & $42 \%$ & $0 \%$ & $14 \%$ \\
South Africa & 0.55 & $0 \%$ & $25 \%$ & $0 \%$ & $20 \%$ \\
\hline
\end{tabular}

